\title{
NEGOCIAÇÃO E CONFLITO NO DIREITO INTERNACIONAL - CINCO MIL ANOS DE REGISTRO DA HISTÓRIA
}

\author{
NEGOTIATION AND CONFLICT IN INTERNATIONAL LAW - FIVE THOUSAND YEARS \\ REGISTERED IN HISTORY
}

Paulo Borba Casella*

\begin{abstract}
Resumo:
'Negociação' e 'conflito' seriam termos essenciais para resumir, em poucas palavras, o sentido da evolução do Direito Internacional. Na sua longa, diversificada e complexa trajetória na história da humanidade, o Direito Internacional se estende por mais de cinco mil anos, desde quando se conservam registros históricos por escrito. Não por acaso, o Direito Internacional se faz presente e necessário, tanto no encaminhamento de posições divergentes, tendendo a alcançar composição, se não amigável, ao menos pacífica - em todas as esferas e manifestações possíveis da 'negociação', desde sempre e em toda parte, como também o Direito Internacional se inscreve e tem papel relevante a desempenhar, quando estes mecanismos 'pacíficos', quer de cunho jurídico ou diplomático, não conseguem dar conta das questões presentes ("jus ad bellum"), e pode ocorrer a necessidade de se ter de passar quer a meios coercitivos para enfrentamento de divergências, ou mesmo chegar ao extremo do conflito armado ("jus in bello") - coarctado pelo Direito Internacional vigente às hipóteses de "legítima defesa", como regulado no art. 51 da Carta da ONU. Como em outros ramos do conhecimento e da atividade humana, os conceitos têm de ser precisados, também no Direito Internacional: seus conteúdos precisam ser claramente delimitados, para que sejam efetivamente entendidos e aplicados. Já advertia Tucídides (c. 465 - c. 395 a.C.), na História da guerra do Peloponeso, "o sentido normal das palavras, em relação aos atos, muda segundo as veleidades dos homens".

Palavras-chave: Negociação. Conflito. Direito Internacional. Retórica. Discurso. Guerra e paz.
\end{abstract}

\begin{abstract}
:
'Negotiation' and 'conflict' are essential terms to summarize, in few words, the sense of the evolution of International Law. Along the complex, long and diversified way of the History of Humankind, International Law extends its scope along more than five thousand years, since the first historical records exist. Not by chance, International Law was present and necessary, as much to conduct diverging positions, aiming to reach settlement, if not friendly, at least peaceful - in all possible areas of 'negotiation'. Since time immemorial and everywhere, International Law is present and has an important role to play, when such 'peaceful'
\end{abstract}

Professor Titular de Direito Internacional Público, presidente da Comissão de publicação da Revista da FDUSP. Presidente do IDIRI - Instituto de Direito Internacional e Relações Internacionais de São Paulo. Coordenador do núcleo de Direito Internacional da ESA - Escola Superior da Advocacia da OAB, São Paulo. 
devices, be they legal or diplomatic, do not manage to handle outstanding issues ("jus ad bellum"), and may lead to the necessity of going beyond same, towards dives for coping with the confrontation of divergences, which may reach the extreme situation of war ("jus in bello") - limited by International Law in force to cases of "legitimate defense", as regulated by art. 51 of the UNO Charter. As in other fields of knowledge and of human activity, concepts have to be precisely stated also in International Law: clearly defined concepts are needed to be effectively understood and applied. As already warned by Thucydides (c. 465 - c. 395 b.C.), in his History of the do Peloponnesian war, "the normal sense of the words, in connection with acts, changes according to the whimsicalities of men".

Keywords: Negotiation. Conflict. International Law. Rhetoric. Speech. War and peace.

Introdução - relações entre história e direito internacional ${ }^{1}$

O que é mais difícil descrever? Inscrever o pensamento do momento no eterno ou captar o que é eterno e inscrevê-lo no momento que passa?

Louis Aragon, Matisse ou la grandeur (1941, éd. orig. 1971, nouv. ed., 1998). ${ }^{2}$

Com seus desenvolvimentos inesperados, a História parece querer nos ensinar que a uma conquista guerreira sucede geralmente outra, totalmente pacífica, no curso da qual o ocupante por sua vez é absorvido por sua conquista. E sem dúvida é assim. Nos casos em que esse fenômeno não se produz, o conquistador se vê rapidamente isolado, afastado do sistema, segregado, reduzido à sua torre de marfim, de onde ele nada mais vê e não conduz mais nada.

Amadou Hampaté Bâ, Vie et enseignement de Tierno Bokar, $1980 .^{3}$

1. A construção do direito, no contexto pós-moderno se inscreve no sentido do tempo histórico e do contexto cultural. Daí decorrem vínculos entre 'direito', 'história' e 'cultura', como modos de estudar e compreender o fenômeno da construção da civilização humana. A percepção dessa necessidade de considerar aspectos diversificados

1 Versão inicial do presente estudo foi apresentada na VI Jornada do Gerar-Grupo de estudos sobre retórica e argumentação, sob coordenação da Prof ${ }^{a}$. Lineide do Lago Salvador Mosca, em 21 de outubro de 2015, sob o tema "Conflito e negociação: a função da argumentação retórica", em 21 de outubro de 2015, no auditório Istvan Jancsó, na Cidade Universitária da USP.

2 ARAGON, Louis. Matisse ou la grandeur. (escrito em nov.-dec. 1941, no vol. Henri Matisse: roman, éd. orig. 1971, nova ed., 1998. p. 17-27, cit. p. 25).

3 BÂ, Âmadou Hampâté. Vie et enseignement de Tierno Bokar: le sage de Bandiagara (Paris: Seuil, (C) 1980, impr. 2004, cit. p. 16). 
em seus amplos campos de aplicação não explica, contudo, como esta se deva fazer e ser desenvolvida, com o fim de ter as ferramentas conceituais e normativas, aptas a serem exercitadas, significativa e eficazmente, sobre a realidade presente.

Tem enorme papel a desempenhar, especificamente, a 'negociação' e o 'conflito' na realidade internacional presente, enquanto tempo histórico e contexto cultural, a partir do qual podemos nos inscrever na busca do conhecimento. Esse direito pós-moderno, que dialoga com as matrizes culturais, simultaneamente integra a realidade internacional presente, e se faz a cada dia: seja para o construir, seja para arruinar as bases do que se tinha construído, no quadro do direito internacional moderno. E esses movimentos respectivos se renovam, sempre.

Dentre múltiplas considerações úteis que poderiam ser desenvolvidas, em relação à interação entre 'direito', 'história' e 'cultura', para os fins desta apresentação, trata-se de considerar o direito internacional, em relação ao conceito de 'negociação' e ao conceito de 'conflito', enquanto bases, para a construção de sistema de direito internacional - onde necessariamente intervirá também o papel da história. ${ }^{4}$ Isso não é simplesmente questão teórica, mas nos concerne a todos, enquanto necessidade, indispensável para assegurar a continuidade da vida no planeta: o aumento do poder de destruição pelas armas torna os limites institucionais e legais, contra o uso unilateral da força, indispensáveis para evitar a destruição de todas as formas de vida sobre a terra!

2. Para os contemporâneos de Francisco Goya, o rosto do inumano era o soldado francês, das forças invasoras, conduzidas sob ordens de Napoleão: este poderia ter esperado que os espanhóis de seu tempo se dessem conta do bem que acreditava lhes trazer, sob a forma da civilização moderna, que lhes dava uma Constituição - a de 1812, inovadora, porém de vida curta - que os livrava do jugo absolutista da família Bourbon, que os fazia mudar de século e lhes proporcionava claro progresso, em relação à precedente dominação, igualmente absoluta da igreja, sobre o conjunto da vida cultural, com limites estritos e muito estreitos a toda atividade intelectual, se fora do que então se compreenderia sob a rubrica da 'ortodoxia'.

E, apesar de tudo, os espanhóis se bateram furiosamente contra esse déspota esclarecido, que queria trazer-lhes a constituição, e algo como um 'estado de direito'. Bateram-se com os meios dos quais dispunham, na época, claramente inferiores estes, em relação aos disponíveis para o exército francês, e muitas vezes, armas tomadas ao acaso, para lutar como pudessem. Até terem acabado com a ocupação francesa, em 1814.

O que virá em seguida, será ainda mais triste. O regime violentamente reacionário de Fernando VII tenta fazer voltar para trás a roda da história. E este será um

CASELLA, Paulo Borba. Fundamentos do direito internacional pós-moderno (prólogo de Hugo Caminos, São Paulo: Quartier Latin, 2008; esp. o item VI, “direito, história e cultura”, p. 491-615). 
aperitivo do que viverão os espanhóis, depois da guerra civil, nas décadas de vigência do duro regime de "Francisco Franco Caudillo de España"!

3. Em nossos dias, o mesmo diálogo de surdos está em curso entre o 'Ocidente' e o mundo muçulmano, paradigmaticamente expresso nas invasões do Iraque, desde 2003, e do Afeganistão, desde 2001, pela coalização dita 'ocidental', dirigida pelos Estados Unidos da América. A reação das populações locais não pode ser compreendida, somente do ponto de vista dos 'ocidentais', como 'ingratidão' em relação aos 'aportes', supostamente valiosos, que lhes são feitos.

Para habitantes islâmicos, para qualquer muçulmano, a invasão de terras do Islão por parte de infiéis (quer dizer, qualquer não muçulmano), acarreta o dever santo de combater (jihad) essa ocupação. Isso obriga a se calarem as vozes moderadas e traz a impossibilidade de qualquer tentativa de diálogo, substituído pela força das armas.

A violência da invasão e dos ataques aos muçulmanos feitos pelos 'ocidentais' explica o recrudescimento do radicalismo muçulmano e o agravamento da perseguição contra as minorias cristãs do Oriente médio, ameaçadas de extinção.

4. Desencontros de tal ordem em nada contribuem para a construção de um 'direito comum para a humanidade', que deve ser entendido no sentido de seu papel para desenvolver a possível visão e também a compreensão do mundo, e do direito. ${ }^{5}$

Por vezes esse alimento pode se tornar bastante indigesto. Como o mostra Goya, na soberba série de desenhos sobre Los desastres de la guerra. É preciso reconhecer a grandeza da obra artística de Goya que não se reduz a panfleto, que nos pretendesse impingir visão maniqueísta da guerra, onde os bons e os maus pudessem ser alinhados por nacionalidade: horror compartilhado é mais humanamente verossímil e nos toca ainda mais fundo. Não existem 'mocinhos' e 'bandidos', passíveis de serem agrupados como grupos nacionais coesos, cada um do seu respectivo lado da fronteira e esta zelosamente guardada, contra as tentativas de invasão, provenientes do 'outro lado'.

A barbárie está dos dois lados! Às vezes nem se veem os rostos, mas se veem os uniformes. Isso não faz nenhuma diferença: o horror está na matança indiscriminada da guerra. A estupidez humana, aumentada pela força das armas, tornada ainda mais mortífera pelos aportes da tecnologia. Ainda mais letal a estupidez humana, quando agravada pela convicção de uma ideologia, de que se matam os opositores do regime, ou pelo discurso fundamentalista de que se mata em 'defesa da fé'.

A ideia de um direito comum para a humanidade, tema de longa tradição intelectual, é exposto em suas principais vertentes, para o tempo atual, por Mireille Delmas-Marty, em seu ensaio Vers un droit commun de l'humanité (entretien mené par Philippe Petit, Paris: Textuel, 1e éd., 1995, 2éd., 2005). 


\section{Ao considerar 'negociação' e 'conflito' no direito internacional em cinco} mil anos de história, não se trata de fazer estudo estritamente histórico, ${ }^{6}$ nem tampouco de ensaio sobre a história da cultura. ${ }^{7}$ Não se trata de encetar estudo de história do direito, ou menos ainda de história do direito internacional pós-moderno. Esta ainda está para ser feita. Seria prematuro tentar fazer o relato histórico desse sistema em formação. Mas tratase de situar o direito internacional, no contexto pós-moderno, em relação à 'história' como à 'cultura'. Trata-se da visão de «longo prazo», de determinar o sentido, ou o fio condutor, a respeito do qual discorrem F. Braudel (1958) ${ }^{8}$ e J. Le Goff (1977). ${ }^{9}$

Por que considerar 'direito internacional', em relação à 'negociação' e ao 'conflito'? Porque toda construção humana deve se reportar ao mundo e ao conceito de mundo, ${ }^{10}$ compreendido enquanto tempo (histórico) e contexto (cultural), no qual este se inscreve.

6 Mas pode-se ter a história como fundo cultural, no propósito de compreender os caminhos do mundo, como expunha Arnold Joseph Toynbee, em seu literalmente monumental A study of History (abridgement by D. C. Sommerwell, London - New York - Toronto: Oxford U.P., vols. 1-6, 1949, vols. 7-10, 1957, vols. 11 e 12 "Reconsiderations" x+740 p., 1961), ou, em português, Um estudo da história (edição revisada e condensada por Arnold Toynbee e Jane Caplan, trad. Isa Silveira Leal e Miroel Silveira, Brasília: Ed. UnB / São Paulo: Martins Fontes, 1987). As lições, formadoras e paradigmas da história, nos foram legadas, desde a Antiguidade, por, Heródoto, Tucídides e Políbio, com o que nos restou de suas obras. Ver Arnaldo Momigliano, As raizes clássicas da historiografia moderna (C) 1990, trad. Maria Beatriz Borba Florenzano, Bauru: Edusc, 2004). Ver tb. a abrangente reflexão sobre a 'história da história' por Hervé Inglebert, Le Monde, l'histoire: essai sur les histoires universelles (Paris: PUF, 2014); Polybe, Histoire (texte traduit, présenté et annoté par Denis Roussel, Paris: Gallimard - Pléiade, 1970); HÉRODOTE - THUCYDIDE, Oeuvres complètes (intr. Jacqueline de Romilly, Hérodote texte présenté, traduit et annoté par André Barguet, Thucydide, texte présenté, traduit et annnoté par Denis Roussel, Paris: Gallimard - Pleiade, (C) 1964, impr. 1982).

7 BURCKHARDT, Jacob. Kulturgeschichtliche vorträge (,,mit einem Nachwort, herausgegeben von Rudolf Marx“, Stuttgart: Alfred Kröner, (C) 1959, no ,posfácio', p. 419-445, ver a observação de Burckhardt ao jovem Bernard Kluger, em uma carta de 1874, cit. p. 419): „Einstweilen geht meine Erfahrung dahin, dass gelehrte Autorschaft eines der ungesundesten und blosses Dozieren (so beschwerlich es sei und so umständlich die dazu gehörigen Studien und Vorbereitungen) eines der gesundesten Metiers auf der Welt ist“. Longo foi o caminho da evolução da história da cultura, desde Burckhardt, até um clássico do século XX como Werner Jaeger, em sua obra prima, Paideia: die formung des griechischen menschen (Berlin: De Gruyter, 1936) ou Kenneth Clark, Civilisation: a personal view (C 1969), até Peter Burke, com seu ensaio What is cultural history? (C) 2004).

$8 \quad$ Fernand Braudel, La longue durée (publ. orig. Annales E.S.C. oct.-déc. 1958, republicado em Écrits sur l'histoire, 1969, e também em Fernand Braudel, Les écrits de Fernand Braudel: les ambitions de l'histoire (éd. établie et présentée par Roselyne de Ayala et Paule Braudel, préface de Maurice Aymard, Paris: Ed. de Fallois, 1997, p. 191-230).

9 Jacques Le Goff, Pour un autre Moyen Âge: temps, travail et culture en Occident: 18 essais (C) 1977, Paris: Gallimard / tel, 2004, "préface", p. 7-15, cit. p. 14): "Un fil conducteur dans cette quête de l'histoire culturelle, un outil d'analyse et d'investigation était nécessaire. (...) en disant avec précaution de quels documents on se sert, et ce que l'on range sous ces notions, je crois à l'efficacité de cet outill'.

10 Paul Clavier, Le concept de monde (Paris: PUF, 2000, cit. p. 4): «Nous pouvons constater, à travers les époques et les générations, à travers les lieux et les milieux, l'existence de différentes façons de concevoir le monde: représentations mythologiques, interprétations scientifiques, doctrines théologiques, organisations politiques, approches économiques, choix éthiques, visions artistiques ... Et, à l'intérieur de chacune de 
6. São necessárias balizas para estar no mundo, sem ser do mundo, nem necessariamente afundar-se no mundo: trata-se de tomá-lo como parâmetro, pois não se pode nem se deve fugir da realidade, porquanto a perda do contato vital com a realidade nos faz descambar para o patológico. ${ }^{11}$ Ao mesmo tempo em que se afirme não necessariamente aceitar que essa realidade seja a única possível, para o mundo. O direito internacional pós-moderno, no contexto cultural e temporal presentes, pode permitir enxergar um pouco mais adiante.

Nesse sentido, mais uma vez o ensinamento de Mireille Delmas-Marty (2005), ${ }^{12}$ no sentido de que «o direito não se deixa reduzir a um jogo de poder. É também a busca de certa sabedoria»..$^{13}$

A medida de restabelecê-lo sobre as bases e os conceitos, que nos legaram o direito internacional de outros tempos, dependerá da extensão, na qual se desejará conduzir o direito internacional pós-moderno, a partir do presente. O direito internacional, enquanto sistema, se baseia na construção institucional, que permite a vida em comum e a regulação legal para ensejar a solução pacífica de controvérsias entre sujeitos de direito internacional. $\mathrm{O}$ que mais e mais se faz de maneira institucionalmente organizada, ${ }^{14}$ por meio de tribunais internacionais e de maneira multilateral.

ces approches, des conceptions divergentes: le monde D'homère n'est pas celui de Dante, ni le monde de Saint Paul celui de Confucius, le monde D'einstein n'est plus, ou plus seulement, le monde de Newton, ni le monde de Picasso, celui de Velasquez. Mais justement, ces différences ne sont significatives qu'à partir d'un tronc commun. Dans La prisonnière Proust écrit que 'l'univers est vrai pour nous tous et dissemblable pour chacun'. C'est une manière de dire que les divergences subjectives d'appréhension et de conception de la réalité supposent une convergence objective. À la racine ou au croisement de ces conceptions divergentes, il doit y avoir une configuration commune, une structure générale des êtres et des événements, un réferentiel dans lequel ces conceptions se complètent ou se contredisent, se rencontrent ou s'ignorent. Un dispositif ou une figure dont partent ou auxquels aboutissent toutes les perspectives subjectives de connaissance et d'action».

11 Philip Sandblom, Enfermedad y creación: cómo influye la enfermedad en la literatura, la pintura y la música (do original Creativity and disease: how illness affects literature, art and music, trad. Angélica Bustamante de Simón, rev. técnica de Hector Perez-Rincón, primeira ed. em inglês, 1982, México: Fondo de cultura econômica, primeira ed. em espanhol, 1995); Barry Panter et al. (editors), Creativity \& Madness: psychological studies of art and artists (Burbank Ca.: Aimed Press, 1995); ou mesmo Gerald N. Izenberg, Modernism and Masculinity: Mann, Wedekind, Kandinsky through World War I (Chicago: the Univ. of Chicago Press, 2000).

12 Mireille Delmas-Marty, Vers un droit commun de l'humanité: entretien mené par Philippe Petit. (Paris: Textuel, $1^{\text {e }}$. éd., 1995, $2^{\mathrm{e}}$. éd., 2005).

13 M. Delmas-Marty (op. cit., 2005, p. 25): «le droit ne se laisse pas réduire à un enjeu de pouvoir. Il est aussi la quête d'une sagesse».

14 Resolução do Institut de droit international, adoptada na Sessão de Berlim, 24 de agosto de 1999, sobre a solução judicial e arbitral de controvérsias internacionais envolvendo mais de dois estados. Ver Le règlement judiciaire et arbitral et arbitral des différends internationaux impliquant plus de deux États, $11^{\mathrm{e}}$ Commission, Rapporteur Rudolf Bernhardt, onde se reafirma que a solução pacífica de controvérsias entre estados, antes concebida como mecanismo essencialmente bilateral, dado o caráter parlamentar e a multilateralidade das relações internacionais pós-modernas se faz, mais e mais frequentemente, com a participação de mais de dois estados. 
Na construção do atual sistema institucional e normativo internacional, aos sujeitos tradicionais de direito internacional, como os estados, doravante comparecem também as organizações internacionais, e os demais agentes, no plano internacional, com papel crescente para os indivíduos. Para estes últimos, os reclamos ainda se fazem ouvir de modo surdo, por não se terem todavia institucionalizado os canais de comunicação internacionais. Não se deixa muito espaço operacional livre para o ser humano, no plano internacional.

7. A construção do diálogo entre as civilizações é assunto crucial para poder permitir a continuidade da vida sobre a terra. Que essa busca seja feita por qual ramo do direito, pouco importa. Será questão de assegurar-lhe a efetividade. Ainda aqui, «a eficácia já observável não basta para fundar uma legitimidade que se oporia aos valores comuns». ${ }^{15}$

A advertência lembrada, em relação a várias civilizações, onde «o homem não existe como tal se não na medida de sua inserção comunitária» me faz pensar na meditação de John Donne, de nenhum homem ser uma ilha «No man is an island». ${ }^{16} \mathrm{Se}$ nenhum homem é uma ilha, que possa viver isolado e de modo autossuficiente, é preciso construir as balizas para a comunicação e o diálogo. É preciso que exista 'negociação', para que se construam pontes, com os semelhantes. Pontes que se construam neste nosso tempo, e também pontes, para conservar o registro da experiência daqueles que nos precederam.

8. Os laços entre 'negociação' e 'conflito', no direito internacional, se apresentam como ferramentas para regular a vida em sociedade, ${ }^{17}$ para excluir ou, ao menos, para limitar o recurso à força, o que em direito penal interno se denomina 'exercício arbitrário das próprias razões', e como tal se tornou caduco e proibido, pelo desenvolvimento institucional. Do mesmo modo, no campo internacional, é preciso excluir o exercício arbitrário das próprias razões. Mas tais pendores primitivos se fazem presentes e atuantes, nas ordens internas, de certa forma, também no contexto internacional.

A escolha deve ser feita de modo claro. Seja para pôr à frente a confrontação, a política de poder (power politics), seja para colocar a ênfase na possibilidade de construir

15 Mireille Delmas-Marty (2005, p. 14): «l'efficacité déjà observable ne suffit pas à fonder une légitimité qui opposerait les valeurs communes».

16 John Donne (1572-1631), Devotions upon emergent occasions and several steps in my sickness (Meditation XVII, 1624): "No man is an island, entire of itself; every man is a piece of the continent, a part of the main. If a clod be washed away by the sea, Europe is the less, as well as if a promontory were, as well as if a manor of thy friend's or of thine own were: any man's death diminishes me, because I am involved in mankind, and therefore never send to know for whom the bell tolls; it tolls for thee".

17 Ely Chinoy, Society: an introduction to sociology (C 1961, 1967). Apesar da importância do conceito, não há acordo sobre o sentido do termo 'sociedade', mesmo entre os especialistas das ciências sociais. 
e de operar estruturas internacionalmente válidas e eficazes, para assegurar a existência e a operação do que se denomina correntemente o sistema internacional. ${ }^{18}$

9. Esse sistema internacional, durante séculos, foi, de modo quase exclusivo, estruturado e operado pelos estados. Mas, ao lado destes, se fazem mais e mais presentes e atuantes outros agentes, como as organizações internacionais, as organizações não governamentais e os indivíduos, aos quais todavia não foram atribuídas funções precisas, nem foram distribuídos os papéis, nem tampouco assinaladas as vias de ação, o que faz aumentar a fragmentação e a aparência de falta de conexão entre as partes desse mesmo sistema ${ }^{19}$ internacional, compreendido enquanto necessidade para a realização de vida ordenada, em comum. Daí o contexto, quer será designado 'pós-moderno', como conteúdos adicionais, onde o direito internacional se virá a vivenciar ou perder.

O direito internacional se faz, em considerável extensão, para os estados e pelos estados. Sem a ação ou a omissão destes, não haveria sistema internacional, por mais elementar que seja. $\mathrm{O}$ direito internacional não pode ser compreendido enquanto sistema abstrato, ou mesmo no absoluto: este é relacional.

Direito não é dado abstrato, passível de ser concebido e estudado em vácuo intelectualmente ideal, ao menos teoricamente ideal; não pode tampouco ser absoluto, mas deverá ser testado, para ter a dimensão prática de sua implementação. Será preciso conceber, apesar de tudo, que este não pode, tampouco, ser reduzido a tais dimensões empíricas, ou ainda permitir que estas sejam postas de modo determinante, para o estabelecimento do conteúdo do sistema.

10. Na busca dos fundamentos do direito internacional pós-moderno, este será concebido, primeiro, como sistema, e a seguir, como implementação desse mesmo sistema. É assim difícil conceber qualquer 'ordem internacional', dada a precariedade intrínseca desta, com disparidades consideráveis em sua interpretação ${ }^{20}$ como em sua implementação.

18 É preciso utilizar com precisão termos que não são neutros, tal como o direito enquanto 'sistema', mas este me parece preferível ao termo 'ordem', que faria supor um conteúdo ordenado, e cujos elementos são preestabelecidos. Devemos, como advertia Samuel Taylor Coleridge, em seu ensaio sobre o estilo, On style: «Se os homens dizessem simplesmente, e com termos simples, o que eles tem a dizer, quão mais eloquentes seriam». A respeito, ver P. B. Casella, Conceito de sistema, contexto internacional e pós-modernidade (no volume Filosofia e teoria geral do direito: estudos em homenagem a Tércio Sampaio Ferraz Junior por seu septuagésimo aniversário, org. Eduardo C. B. Bittar e João Maurício Adeodato, São Paulo: Quartier Latin, 2011, p. 999-1.024).

19 Na medida em que não possa ser evitado, caberá precisar em que sentido, o termo será utilizado. Segundo Martin Heidegger, cada questão, de certo modo, compreende já uma intuição da resposta, a respeito do que é perguntado. Já pelo modo como é feita a indagação.

20 Serge Sur, L'interprétation en droit international public (Paris: L.G.D.J., 1974); S. Sur, La coutume internationale (Paris: Litec, 1990); S. Sur, Système juridique international et utopie (Le droit international, Archives de philosophie du droit, tome 32, Paris: Sirey, 1987, p. 35-45); S. SUR, Vérification en matière de désarmement (RCADI, 1998, t. 273, p. 9-102); S. Sur, Relations internationales (Paris: Montchrestien, $1 \mathrm{a}$. 
Essa questão da implementação é ao menos tão relevante quanto a da definição dos conceitos ordenadores do sistema. Como se dá em relação a conceitos cruciais como ‘negociação’ e ‘conflito’. A aplicação se faz no plano internacional, ou mais precisamente, em diferentes planos internacionais, bilaterais ou multilaterais, de vocação universal ou regional, no quadro de organizações internacionais de caráter político, técnico ou científico, nas relações internacionais entre países desenvolvidos, como entre estes e países ditos 'em desenvolvimento', como, ao mesmo tempo os países 'menos desenvolvidos', entre uns e outros, seja em contextos bilaterais ou multilaterais.

11. As relações entre os estados podem ser feitas segundo a aplicação do direito, como podem igualmente fazer-se, por meio do uso unilateral da força e da imposição. Ou ainda, segundo graus variáveis, e as mais diversificadas gradações entre uma e a outra, entre 'negociação' e 'conflito'. Todo o conjunto dessas relações internacionais, ao mesmo tempo, terá dimensão política como consequências jurídicas, e estas poderão variar, segundo graus consideráveis. A identidade dos sujeitos e dos agentes não será destituída de repercussões sobre a avaliação e as consequências dos atos.

A construção do direito internacional pós-moderno está em curso. Não será, assim, por acaso, mas decorre de imperativos categóricos, no sentido kantiano do termo, segundo o tempo (histórico) e o contexto (cultural), nos quais se inscrevem os sujeitos (e os demais agentes) no plano internacional, ${ }^{21}$ nesse mundo pós-moderno: o procedimento de revisão e de reavaliação do direito internacional, legado por outros períodos está na sua hora, e será questão de medir quanto permanece válido e poderá sobreviver às operações correntes de 'negociação' ou de 'conflito', para ser revisitado e submetido a reavaliação, desde a base, e de modo a poder ser mantido em condições tanto conceitual quanto operacionalmente válidas. Cabe indagar se e em que medida esses conceitos e instituições permanecerão válidos.

12. O sistema de direito internacional pós-moderno está em via de construção, mas, todavia, se encontra em obras. O pós-moderno está centrado no temporário, nos dados que fluem, no transitório e menos no que está consolidado pela história, e assim se inscreve no quadro contemporâneo.

ed., 1995; 3. ed., 2004).

21 Em 1932, apresentava M. Siotto Pintor, Les sujets de droit international autres que les états (RCADI, 1932, t. 41, p. 245-362). Ver tb. Laurence Boisson de Chazournes e Rostane Mehdi (coord.), Une société internationale en mutation: quels acteurs pour une nouvelle gouvernance? (Bruxelles: Bruylant, 2005, l'introduction de Rostane Mehdi, 'mutations de la société internationale et adaptations insitutionnelles: le grand défi', p. 7-18, item ii 'participation des acteurs non-étatiques et bonne gouvernance'); Habib Gherari e Sandra Szurek (coord.), L'émergence de la société civile internationale: vers la privatisation du droit international? («actes du colloque des 2-3 mars 2001, org. sous les auspices de M. Hubert Vedrine, Ministre des affaires étrangères», Paris: Pedone/ CEDIN Univ. Paris X, Cahiers internationaux, n. 18, 2003). 
As nações 'civilizadas'22 deverão se mostrar à altura das necessidades operacionais do direito internacional pós-moderno. Por meio da diferente reação dos sistemas nacionais de direito, diante da ordem jurídica mundial, em face da estrutura do pensamento pós-moderno.

A complexidade e a extensão da tarefa são enormes. Os resultados se fazem presentes, na medida e segundo graus variáveis, onde interferem nuances regionais, ao mesmo tempo em que cumpre considerar, no seu conjunto, um sistema de direito internacional pós-moderno, e assegurar que este possa ter vocação mundial.

13. Em que medida esse direito internacional pós-moderno poderá ser estruturado, de modo a poder validamente ter alcance sobre a realidade política da 'negociação' e do 'conflito', que pode chegar ao uso unilateral da força, como servir-se das pressões, que podem simultaneamente ser econômicas, comerciais, ambientais, da imperiosa necessidade de preservação dos recursos naturais ${ }^{23} \mathrm{e}$, ainda, da viabilidade da conservação da vida inteligente no planeta, como para as estratégias (militares, econômicas ou políticas), ou em relação com o acesso aos recursos naturais, como aos mercados, ou variáveis de cada um destes, para poder aceder a regulação juridicamente eficaz, de tais questões e tais necessidades? A conclusão é clara: na medida em que a tarefa se encontra todavia em curso, pode ser prematuro tentar determinar quais serão os seus resultados.

As necessidades existem e são perceptíveis. Durante a construção, a percepção do conjunto da obra projetada pode não ser clara, para aqueles que vejam o canteiro, de fora, sem o conceber como conjunto (ao menos teoricamente) ordenado, mas na realidade do caos das diferentes atividades, que poderão levar à consecução do resultado, uma vez construído. Pode, às vezes, não ser evidente, mesmo para aqueles que estiverem dentro, e engajados na construção desse direito internacional pós-moderno. Ao mesmo tempo, nem se pode conceber nem tampouco esperar que todo o sistema, no seu todo, esteja pronto, antes que este se possa mostrar, o que poderia ser demorado demais, e correria o risco de estar ultrapassado, mesmo antes de se ter completado.

22 Hugh Thirlway, Concepts, principles, rules and analogies: international and municipal legal reasoning (RCADI, 2002, t. 294, p. 265-406, cit. p. 274): “Article 38 includes among the recognized sources of law the 'general principles of law' recognized in the legal systems of 'civilized nations'. As you will be aware, there are differing views as to the meaning of the reference in the Statute to those principles; but for most scholars, the correct interpretation would at least include the principles which can be found to be shared by all, or at least most, national legal systems. The reference to general principles of law was included in the Statute of the Permanent Court essentially to ensure that the Court should not, for lack of a customary or conventional rule, be obliged to declare a non-liquet, that is, decline to give a decision. Is the effect of article 38 that such principles form part of international law, or are they something existing outside it which can, when necessary, be transposed to the plane of international relations?".

23 George Elian, Le principe de la souveraineté sur les ressources nationales et ses incidences juridiques sur le commerce international (RCADI, 1976, t. 149, p. 1-85). 
14. O momento atual do direito internacional pós-moderno pode ser compreendido quando se faz paralelo com a obra de pensador como Ludwig Wittgenstein: o trabalho, feito pelo pensador, poderia confessar as suas objeções de forma, em razão dos limites de seu autor, mas tinha a convicção, quanto ao seu objeto. ${ }^{24}$

Para Wittgenstein"25 "no campo da filosofia, a dificuldade consiste em não dizer mais do que se sabe". ${ }^{26}$ A mesma lição pode e deve ser reconhecida e vivida, também no direito internacional pós-moderno. E a advertência permanece tanto necessária quanto válida.

Desse modo, cumpre trabalhar com cuidado e com humildade, para tentar fazer contribuição útil, na construção e na delimitação dos fundamentos do direito internacional pós-moderno, e explicitar a relação deste com a 'negociação' e com o 'conflito'. Cumpre ao direito internacional desempenhar papel crucial, para construir e assegurar a manutenção de grau normativo e institucional de equilíbrio no mundo pósmoderno, de modo a ver as relações internacionais se ordenarem preferencialmente segundo princípios, mais que sobre relações de constrição e de poder. Entre os modelos de força (ou de 'conflito') e os modelos jurídicos (ou de 'negociação'), a escolha deve ser claramente apresentada, para determinar a direção e o sentido no qual se orientará a construção.

A lição central do direito internacional pós-moderno será de mostrar ser possível reger as relações internacionais segundo normas jurídicas, desde que se preserve grau mínimo de consistência na determinação dos princípios, na interpretação das normas, como na aplicação dos procedimentos de implementação do sistema - no sentido da 'negociação'. Como se faz em cada sistema institucional e jurídico nacional, a institucionalização é o caminho para apaziguar a conflitualidade, inerente à natureza humana, especialmente na vida em sociedades.

24 Ludwig Wittgenstein, Tractatus logico-philosophicus (edição original Logisch-philosophische Abhandlung, 1921, (C) Routledge \& Kegan Paul Ltd, 1961, «prefácio do autor») afirmava que se o trabalho dele tivesse algum valor este seria duplo. Primeiro, por exprimir os seus pensamentos, e este seria tanto mais adequado quanto melhor estivessem expressos os seus pensamentos. Nesse sentido, ele se afirmava consciente de estar muito aquém do possível, simplesmente porque "minhas forças são reduzidas para cumprir essa tarefa. Possam outros fazê-lo melhor". Ao mesmo tempo, afirmava, a verdade dos pensamentos comunicados parecia a ele irretocável e definitiva, de tal modo que pensava ter podido resolver o que era essencial: "Se eu não me engano, o segundo dos valores deste trabalho é o de mostrar o pouco que se pode alcançar, quando se resolvem tais problemas".

25 Ludwig Wittgenstein, Los cuadernos azul y marrón (do original The blue and brown books, trad. de la 2. ed. inglesa por Francisco Gracia Guillén, prefácio de Rush Rhees, Madri: Tecnos, 1. ed., 1968, 2a . reimpr., 1984).

26 Wittgenstein, Los cuadernos azul e marrón (ed. cit., p. 77). 
15. Igualmente a lição de Immanuel Kant mereceria cuidadosa meditação, tal como se nos apresenta, no breve ensaio sobre a Idéia de história universal de ponto de vista cosmopolita (1784), ${ }^{27}$ a dificuldade em

disfarçar certo dissabor quando se observa a conduta humana, colocada no grande cenário mundial, e muitas vezes o que isoladamente, aparenta sabedoria ao final mostra-se no seu conjunto, entretecido de tolice, capricho infantil e freqüentemente também de maldade infantil e vandalismo: com o que não se sabe ao cabo que conceito se deva formar dessa nossa espécie, tão orgulhosa de suas prerrogativas. $^{28}$

A construção do direito internacional pós-moderno poderá servir como sinalizador do percurso a ser percorrido e terá, assim, cumprido a sua missão. A partir daí, cabe a cada época encontrar os elementos necessários, para a construção do raciocínio e das fundações destes, de modo a poder assegurar a coerência e a consistência do todo.

Ainda do mesmo ensaio de Kant (1784):

como o filósofo não pode pressupor nos homens e seus jogos, tomados em seu conjunto, nenhum propósito racional próprio, ele não tem outra saída, senão tentar descobrir, no curso absurdo das coisas humanas, um propósito da natureza, que possibilite todavia uma história, segundo um determinado plano da natureza, para criaturas que procedem sem um plano próprio. Queremos ver se conseguimos encontrar um fio condutor para tal história e deixar ao encargo da natureza gerar o homem que esteja em condição de escrevê-la, segundo esse fio condutor. ${ }^{29}$

16. Acrescentaria, sem acreditar trair o espírito da reflexão kantiana, talvez a construção de vínculos entre o direito internacional, a história e a cultura possa desempenhar o papel de fio condutor. Como mostram os conceitos de 'negociação' e de 'conflito'.

27 Immanuel Kant, Idéia de uma história universal de um ponto de vista cosmopolita (de l'original Idee zur einer allgemeinen Geschichte in weltbürglicher Absicht, org. R. Terra, trad. R. Naves et R. Terra, São Paulo: Martins Fontes, 1. ed., 1986, 2. ed., 2004).

28 I. Kant (op. cit., 1784, ed. 2004, p. 4).

29 I. Kant (op. cit., 1784, ed. 2004, p. 4-5) observa que o filósofo não pode deixar de atribuir aos homens em seus jogos, tomados como conjunto, algum fim racional próprio, não tem assim outra saída senão tentar descobrir, no curso absurdo das coisas humanas, um fim da natureza, que torne possível uma história segundo plano determinado pela natureza, para seres que procedem sem um plano próprio. Seria, assim, a tentativa de encontrar um fio condutor para tal história, e deixar à a cargo da natureza encontrar o homem que teria a condição de escrever, segundo esse fio condutor. De onde o papel do filósofo e da filosofia, para ajudar na compreensão do mundo. 
Mais uma vez, Kant, na sua Lógica (1800), ${ }^{30}$ assinala ser

toda a natureza, em geral, estritamente nada além de interdependência (Zusammenhang) dos fenômenos, segundo normas, e em parte alguma ocorre ausência de normas. Ao crermos constatar uma tal ausência, podemos somente dizer que nesse caso as normas nos são desconhecidas. ${ }^{31}$

Neste mundo pós-moderno, onde as balizas podem parecer menos claras e menos evidentes, exceto se nos deixarmos levar por uma ou outra modalidade de fundamentalismo, que afaste todas as dúvidas e proíba todas as questões, sob pena de afastar, ao mesmo tempo, a complexidade da realidade e as dificuldades de atingir a compreensão, temos de permanecer no mundo, sem nele soçobrar, sem nos submeter aos imperativos da força: o que é um pesado encargo, para cada um de nós. É justamente isso que nos faz humanos - de onde vêm os laços entre direito internacional, 'negociação' e 'conflito' - ainda uma vez.

A missão de construir pontes, para permitir estabelecer vias para a compreensão entre os homens é uma missão para o direito internacional e para o direito comparado. Como se passa a considerar no 'enquadramento do tema'.

Enquadramento do tema

Duas coisas são necessárias ao homem, para a realização
de qualquer ato, a saber, a vontade (voluntas) e a potência
(potestas); quando falte uma das duas, ele será incapaz de
executar qualquer coisa. Se faltar a vontade, não se fará
sequer o que não se deseja; e sem o poder de executar, a
vontade não serve para nada.

Boécio (470-525), De Consolatione philosophiae ${ }^{32}$

30 Immanuel Kant, Logique (1800, trad. L. Guillermit, Paris: Vrin, (c) 1966, 2e éd., revue et augmentée, 1970, cinquième tirage, 1997).

31 Para I. Kant (op. cit. ed. cit., introduction: I. concept de la logique, p. 9), toda a natureza em geral não é estritamente nada além de uma interdependência (Zusammenhang) dos fenômenos segundo as normas, e em parte alguma deixam de ocorrer as normas. Se acreditamos constatar uma tal ausência, nós podemos somente dizer que nesse caso as normas nos são desconhecidas.

32 Boèce, La consolation de la philosophie (traduction nouvelle en prose et en vers avec le texte en regard par Louis Judicis de Mirandol, Paris: Guy Trédaniel / Ed. de la Maisnie, 1981, Livro IV, III, p. 210-211); b/c na edição, Boèce, La consolation de la philosophie / Philosophiae consolationis (traduction nouvelle avec une introduction et des notes par Aristide Bocognano, Paris: Garnier, 1937, Livro IV, Prosa 2, p. 158-159): «Duo sunt, quibus omnis humanorum actuum constat effectus: voluntas scilicet ac potestas, quorum si alterutrum desit, nihil est quod explicari queat. Deficiente etenim voluntate, ne aggreditur quidem quisque quod non vult; at si potestas absit, voluntas frustra sit». 
Todos os homens, cuja natureza superior os impulsiona para o amor da verdade, devem acima de tudo levar em conta isto: assim como tiveram a vantagem de se beneficiarem dos esforços dos antigos, devem trabalhar para que os pósteros, para que a posteridade possa servir-se do fruto de seus esforços.

Dante Alighieri (1265-1321), De Monarchia ${ }^{33}$

17. Para proceder ao enquadramento do tema, lembraria as duas lições, acima referidas, uma de Boécio e outra de Dante. Separados por alguns séculos, ambos se coadunam com o sentido que gostaria de imprimir à presente exposição.

Aqui se propõe considerar a enormidade da tarefa, consistente em 'negociação' e 'conflito', tal como estas se põem ao longo de 'cinco milênios do direito internacional' - justamente esse marco coincide com a existência de história escrita, quer por meio de inscrições em pedra, em ossos, em metais, em placas de cera ou de barro, como de outros documentos de época.

O fio condutor aqui proposto é a presença permanente destes dois elementos: a 'negociação' e o 'conflito', com a contraposição e a interação de ambos, no direito internacional, que se estende desde quando se conservaram registros escritos de acordos por volta de 3100 a.C. até os dias atuais.

Apresento aqui parte dos resultados de trabalho de ao menos quarenta anos de leituras e publicações dos últimos cinco anos, sobre 'direito internacional no tempo', do qual escrevi cinco volumes (já foram publicados quatro) para conseguir chegar até 1815 - ainda tendo pela frente os últimos duzentos anos ... - o que serve para dar dimensão da enormidade da tarefa, já encetada e ainda por fazer!

A fundamentação da presente exposição está nesses livros. Onde também podem ser encontradas as referências bibliográficas pertinentes, que seria impossível reproduzir aqui em sua inteira extensão. E aos quais se remete. ${ }^{34}$

33 Dante Alighieri, De Monarchia (in Tutte le opere, a cura di Luigi Blasucci, Firenze: Sansoni, primeira edição, 1965, quarta edição, 1989, p. 247-316, cit. I.1, p. 250): «Omnium hominum quos ad amorem veritatem natura superior impressit hoc maxime interesse videtur: ut, quemadmodum de labore antiquorum ditati sunt, ita et ipsi posteris prolaborent, quatenus ab eis posteritas habeat quo ditetur. » Prosseguia Dante, na mesma passagem, assinalando o quanto se pode considerar, de fato, longe do próprio dever, para quem tem a possibilidade de se instruir, ter sido educado mediante ensinamentos públicos, em descuidar de aportar a sua própria contribuição, às coisas de interesse público: «Longe namque ab offitio se esse non dubitet qui, publicis documentis imbutus, ad rem publicam aliquid afferre non curat».

34 Como referências bibliográficas, que fundamentam o trabalho: CASELLA, Paulo Borba. Direito internacional no tempo clássico (São Paulo: Atlas, 2015, xviii+760 p., ISBN 9788597001846); Casella, Direito internacional no tempo moderno de Suarez a Grócio (São Paulo: Atlas, 2014, xxx+665 p., ISBN 9788522482870); Casella, International development law and the right to development in post-modern international law (in Droit international et nouvelles approches sur le tiers-monde: entre répétition et renouveau / International law and new approaches to the third world: between repetition and renewal, 
18. Lembraria, igualmente a distinção a ser feita, acompanhando Aristóteles, na Poética (9 e 23), ${ }^{35}$ quando este distingue 'poesia', que segundo o filósofo, descreve o geral ( ta kat'holou) e a 'história', que se interessa pelas especificidades humanas, catálogo de ações, que se exprimem em perspectiva racional (kata logon).

Contra essa visão, por sua vez, Políbio, na sua História,${ }^{36}$ argumenta que certo tipo de 'história' pode visar o geral e aceder à compreensão do mundo - mais do que a 'poesia'. Entre os dois podemos construir caminho para o exame do tema desta apresentação.

19. Segundo expunha Políbio, a história do mundo habitado (oikumene) (I, 3, 3-4), que se encontrava antes dispersa, em diversos teatros de operação, «se tinha tornado um todo orgânico» ${ }^{37}$ quando os eventos da Itália e da África se tinham entrelaçado com os da Ásia e da Grécia «em conjunto tendendo a único e mesmo fim (telos)» (V,105, 4-9): as interconexões (symploke) passaram a formar 'todo orgânico' - ou, como hoje diríamos, configura o fenômeno da 'globalização'.

sous la direction de Mark Toufayan, Emmanuelle Tourme-Jouannet e Hélène Ruiz-Fabri, Paris: Société de législation comparée, 2013, p. 261-280); Casella, A proteção internacional dos direitos das minorias: o caso da minoria por orientação sexual e identidade de gênero (in Direito à diferença: aspectos teóricos e conceituais da proteção às minorias e aos grupos vulneráveis, coord. Liliana L. Jubilut, Alexandre G. M. F. Bahia e José Luiz Q. de Magalhães, São Paulo: Saraiva, 2013, p. 179-188); Casella, Direito internacional no tempo medieval e moderno até Vitória (São Paulo: Atlas, 2012, x+654 p., ISBN 9788522473120); Casella, Direito internacional no tempo antigo (São Paulo: Atlas, 2012, xiv+472 p., ISBN 9788522462957); Casella, Empires, hegemony and cooperation (in Pravovie Aspecti BRICS - Aspetti giuridici del BRICS - Legal aspects of BRICS, ed. by T. A. Alexeeva \& P. Catalano, São Petersburgo: Univ. Nacional de Pesquisa, 2011, p. 27-48); Casella, Conceito de sistema, contexto internacional e pós-modernidade (no volume Filosofia e teoria geral do direito: estudos em homenagem a Tércio Sampaio Ferraz Junior por seu septuagésimo aniversário, org. Eduardo C. B. Bittar e João Maurício Adeodato, São Paulo: Quartier Latin, 2011, p. 9991024); Casella, Evolução institucional do direito internacional: à luz do cinquentenário do conceito de direito de Hart (1961) (Homenagem aos 70 anos do prof. Celso LAFER, org. Tércio Sampaio Ferraz Jr. e L. O. Baptista, Revista Brasileira de Filosofia, São Paulo, 'edição comemorativa', ano 60, v. 236, jan.jun. 2011, p. 313-329); Casella, International Law: the post-modern approach to the classics and the new challenges (curso ministrado no Rio de Janeiro, em agosto de 2009, publ. XXXVI Course on Iinternational Law, org. Comité jurídico interamericano da OEA, realizado, Washington: OEA - Secretaria general, 2010, p. 3-46); Casella, Il Foedus tra Plebe e Senato ed il problema del Diritto Internazionale. Dalla secessione della Plebe all'autodeterminazione dei popoli, in: Diritto@Storia, Rivista Giuridiche e Tradizione Romana. N. 9 -2010, ISSN 1825-0300); Casella, Direito internacional dos espaços (São Paulo: Atlas, 2009); Casella, $A b z$ : ensaios didáticos (prefácio João Grandino Rodas, São Paulo: Imprensa Oficial do Estado, 2008; $2^{\text {a }}$. tiragem, 2009); Casella, Fundamentos do direito internacional pós-moderno (prólogo de Hugo Caminos, São Paulo: Quartier Latin, 2008); Casella, Tratado de Versalhes na história do direito internacional (texto integral em português, com introdução, São Paulo: Quartier Latin, 2007).

35 Aristotle, Poetics (original grego com trad. em inglês por Stephen Halliwell, Cambridge Ma. / London: LCL 199, Aristotle XXIII, (C) 1995, reprinted with corrections, 1999, reprint 2005); tb. na edição Aristóteles, Poética (trad., comentários, índices analítico e onomástico de Eudoro de Souza, São Paulo: Abril, 1973).

36 Políbio (ca. 202 - ca. 120 a.C.), História. Utilizada a edição Polybe, Histoire (texte traduit, présenté et annoté par Denis Roussel, Paris: Gallimard - Pléiade, 1970).

37 Polybe, Histoire (texte traduit, présenté et annoté par Denis Roussel, Paris: Gallimard - Pléiade, 1970, «préface», livre premier, p. 1-5, cit. p. 3): «a história do mundo passou a formar um todo orgânico». 
A especificidade da história universal (tes katholikes kai koines historias) resultaria do fato de ter esta natureza distinta das histórias 'particulares', ou nacionais, ou regionais: para enxergar o mundo, é preciso ampliar o campo de visão. Em Políbio a História universal (katholiké) (I, 3; V, 31; VI, 5, 3) ou comum (koiné) (VIII, 2, 11), como conhecimento certo (mathema), é saber superior à poesia: a história contém intriga, explicação e reserva de exemplos de vida. A visão de conjunto (synopsis) tem fundamento objetivo na unidade orgânica de todo o cosmos - como clara herança dos pensadores estoicos - e isso é algo que Políbio reencontra no encadeamento de fatos históricos.

A universalidade da história se fez, segundo Políbio, pela convergência das histórias, separadas: a história 'geral' se 'globalizou' pela ação dos Romanos, quando estes configuraram mundo unificado. A unidade de ação do relato polibiano nos traz a história mundial, que como tal, passava a existir.

A intuição da unificação da história está no cerne das reflexões atuais sobre 'globalização' em mundo conectado. Mas com a diferença que é raro aparecer o nível de reflexão metodológica e filosófica de um Políbio, para alcançar compreensão total.

20. Serão concomitantes as perspectivas 'geográfica' e 'histórica', para a percepção e a compreensão do Direito Internacional, condicionados tanto pelo tempo, como pela geografia, e pela configuração cultural. A perspectiva geográfica é condicionada e marcada pelo espaço e pelo tempo: ambas interagem na gênese e no funcionamento do direito internacional - 'tempo' e ‘espaço' estão presentes, de modo recorrente, enquanto modos de ver e de explicar o mundo.

O dilema 'crono-espacial' está muito presente no direito internacional, que de 'europeu', durante séculos, e depois, 'europeu e americano', se quer transmutar, além dos traumas vividos na 'colonização' e na 'descolonização', em sistema institucional e normativo de caráter verdadeiramente 'mundial': isso não é fácil, nem está integralmente feito.

Daí o sentido de se buscar o tratamento do direito internacional na perspectiva 'histórica': acarreta concomitante perspectiva geográfica. Este Direito Internacional, como o temos hoje, não é uno, nem no tempo, nem no espaço, mas anseia pela unidade, pela universalidade, e pela tentativa de alcançar um «todo orgânico» polibiano.

21. Ao considerar o direito como base para a ordenação da vida em sociedade, pode-se enfatizar o papel do direito, da boa lei (eunomia) como base para a ordenação da vida em sociedade, no plano interno, como na vida internacional, e isso se enquadra na 'negociação', o que se contrapõe ao fenômeno oposto, da falta de lei (anomia), que se exprime no 'conflito'. Como modelo cultural concorrente, a 'anomia' é tenebrosa, e traz a expressão da barbárie, no sentido de instauração do reino da força: não se pode admitir somente a força ou a ameaça do uso desta, como os motores que movem 
e regem o mundo - e, justamente, o direito internacional responde de outro modo a esse anseio de ordenação e de instauração de patamares de convivência organizada.

É preciso acreditar que a convivência entre os homens possa ter valores e procedimentos ordenados. Como base para a ordenação desta. Assim como se faz a convivência entre os estados, esta 'vida em comum' dos estados se possa construir sobre arcabouço institucional e normativo, com bases éticas, teleologicamente humanas, para ordenação do direito e da sociedade internacionais. O que se entende por 'negociação'.

22. Dentre algumas configurações possíveis, para descrever e caracterizar a alternância de 'negociação' e 'conflito', algumas civilizações podem ser apontadas, com caráter paradigmático. Hoje, aqui, destacaria as seguintes:

- $\quad$ entre as cidades estado da Mesopotâmia;

- na civilização chinesa antiga, em seu sistema internacional 'sinocêntrico';

- $\quad$ papel da força e do direito internacional no Antigo Testamento;

- a internacionalidade no antigo império persa e (a complicada relação com) as cidades estado gregas;

- caráter abrangente do direito internacional (jus gentium) na formação e no desenvolvimento de Roma;

- conceito de 'guerra justa' (bellum justum) e transmissão do legado greco-romano;

- $\quad$ elos de transmissão civilizacional e o direito das gentes no Islão;

- contextualizar a guerra e direito da guerra medieval - entre 'jihad' e 'cruzadas' com influência sobre Europa moderna;

- negociação e conflito entre russos e chineses - paz e o uso do chá;

- fundamentos do direito internacional e regulação da convivência;

- conclusão: o direito internacional na história, ante as lições de Boecio e Dante.

23. Da Mesopotâmia nos vem os primeiros registros de 'negociação' e de ‘conflito' na história do direito internacional: o primeiro tratado, do qual se tem notícia escrita, no sistema das cidades-estado da Mesopotâmia, fixava as fronteiras entre as cidades de Lagash e Umma, com participação de Mesilim, soberano do vizinho estado de Kish. Esse acordo é normalmente datado por volta de 3100 a.C. ${ }^{38}$

O marco histórico de surgimento do direito internacional e das suas manifestações iniciais coincide com os primeiros registros da História escrita - onde temos o direito internacional como parte da construção da civilização. O propósito central - a 'negociação', para superar o 'conflito' - está presente e se encontra expresso, desde

38 Casella, Direito internacional no tempo antigo (São Paulo: Atlas, 2012, esp. parte I. direito das gentes no mundo antigo, título I. elementos precursores de direito internacional na Antiguidade, cap. III - civilizações antigas entre hegemonia e relações internacionais, p. 165-232). 
o advento de tais elementos precursores de direito internacional, quer se trate de base convencional ou consuetudinária.

24. De modo equivalente, uma configuração de ordem mundial chinesa antiga, surgiu, na Ásia oriental, em decorrência de toda uma rede de relações entre China e outras potências regionais, que se aproximava do modelo correspondente de ordem internacional, como se desenvolveu na Europa. Essa assim chamada "ordem mundial chinesa", na formulação de Onuma Yasuaki $(2010)^{39}$ e John King Fairbank $(1989,1970),{ }^{40}$ tinha a China antiga como o centro de sistema internacional 'sinocêntrico'.

As demais potências gravitavam em torno desse eixo 'sinocêntrico': não havia ideia de coordenação, mas de subordinação e 'vassalagem', ainda que somente nominal, virtualmente era exercitada - como símbolo. Os dignatários estrangeiros, ao serem recebidos, prestavam homenagem ao imperador chinês, reunido em solene aparato oficial, circundado por sua corte. Além da homenagem formal, também se negociavam acordos de comércio.

Existia e operava, assim, a ideia de 'sistema internacional', na Ásia oriental, tendo como centro a China, mas este 'sistema' se fazia a partir de premissa, por assim dizer, imperial (relação entre centro civilizado e periferias). O sistema internacional sinocêntrico não se punha sob a forma de coordenação entre iguais, mas como relação entre 'centro' e periferias. ${ }^{41}$

25. Da China antiga ao contexto atual, podem ser feitas algumas comparações:

- na China antiga, as relações internacionais relacionadas com a prestação de tributo e reconhecimento de suzerania, ou ao menos precedência do Imperador chinês em relação a outros soberanos;

- o sistema chinês antigo partia de centro - justamente o 'Império do meio' - em relação a periferias, que prestavam tributo, ainda que nominal, ao poder central;

- o mesmo eixo de poder - o imperador, como 'filho do céu' - norteava tanto o sistema interno chinês quanto o internacional, onde o equilíbrio das relações internas e das relações internacionais refletia a benção divina, dispensada ao

39 ONUMA, Yasuaki. A transcivilizational perspective on international law (RCADI, 2009, v. 342; tb. publ. Haia: Pocketbooks of the Hague Academy of International Law, 2010); ver tb. Onuma Yasuaki (edited by), A normative approach to war: peace, war and justice in Hugo Grotius (Oxford: Clarendon Press, 1993).

40 John King Fairbank and Edwin O. Reischauer, China: tradition \& transformation (C) 1978, Boston: Houghton Mifflin Co., revised ed., 1989); J. K. Fairbank (ed.), The Chinese world order: traditional China's foreign relations (Cambridge, Ma.: Harvard Univ. Press, (C) 1968, $2^{\text {nd }}$. printing, 1970, esp. J. K. Fairbank, $A$ preliminary framework, p. 1-19).

41 Casella, Direito internacional no tempo antigo (São Paulo: Atlas, 2012, cap. VII - entre as civilizações do continente asiático, p. 335-410, esp. item 7.2 - a China antiga, p. 358-389). 
imperador;

- $\quad$ o centro de poder ao menos buscará revestir-se de roupagem jurídica, para não dar a aparência de exercitar a força de modo arbitrário.

No caso chinês, o próprio conceito de 'sistema internacional', partia do pressuposto da subordinação dos estados periféricos e tributários ao poder central chinês. ${ }^{42}$ Esses dados são relevantes não somente para compreender o passado, como também servem de chave para compreender o presente.

Por sua vez, no sistema internacional ocidental, não obstante as suas desigualdades de fato, se tinha configurado a partir da concepção de paridade e de equilíbrio de poder, entre iguais, ou até certo ponto, mais ou menos iguais, até o reconhecimento do valor intrínseco da 'igualdade jurídica' entre os estados, integrantes do sistema.

26. A relação entre 'força' e 'direito' também se faz presente no Antigo testamento: vários livros do antigo testamento, tais como Juízes, Samuel, Ester e Reis sancionam atrocidades sem nome, cometidas contra "os gentios" - desde que perpetradas pelo autodenominado "povo eleito" - sem proporcionar aos povos, que supostamente tem de ser exterminados, quaisquer meios e modos de questionar os fundamentos para a condição da 'eleição' deste, que assim se autodenomina.

Além das barbaridades cometidas, também emanam de vários livros da Bíblia $^{43}$ os relatos insuflados por ideais de paz, proclamados pelos profetas. Dentre estes, talvez a mais bela passagem seja Isaías (Isaías 2.4) no sentido de que depois do advento do Messias, converter-se-iam as espadas em arados e as lanças em foices; não mais desembainhará a espada povo contra povo, nem mais se adestrarão na guerra: "conflabunt gladios suos in vomeres, / Et lanceas suas in falces. / Non levabit gens contra gentem gladium, / Nec exercebuntur ultra ad praelium".

Arthur Nussbaum (1947) $)^{44}$ denominava esta "a contribuição mais importante do povo judeu para a história do direito internacional”, enquanto Charles Fenwick (1934) ${ }^{45}$ observava que "mesmo os judeus, apesar dos ideais de paz, proclamados pelos profetas,

42 Como se considera em Casella, Direito internacional no tempo antigo (São Paulo: Atlas, 2012, cap. VII entre as civilizações do continente asiático, p. 335-410, esp. item 7.2 - a China antiga, p. 358-389).

43 BIBLIA. Biblia sacra iuxta Vulgatam Clementinam: logicis partitionibus aliisque subsidiis ornata a R. P. Alberto Colunga et Laurentio Turrado. 5. ed. Madri: Biblioteca de Autores Cristianos, 1977; ou tb. na edição 'protestante', BÍBLIA SAGRADA: nova versão internacional (São Paulo: Sociedade Bíblica Internacional, 2000).

44 Arthur Nussbaum, Historia del derecho internacional (do original A concise History of the Law of Nations (C) 1947, trad. Francisco Javier Osset, adiciones sobre 'História de la doctrina hispanica de derecho internacional' por Luís Garcia Arias, Madri: Revista de Derecho Privado, s/d, prólogo de L.G.A. datado “1949”).

45 Charles G. Fenwick, International law (1 ${ }^{\text {st }}$. publ., 1924, New York / London: D. Appleton-Century Co. Inc., $2^{\text {nd }}$ ed. revised and enlarged, 1934); ver tb. Fenwick, The progress of international law during the past forty years (RCADI, 1951, t. 79, p. 1-72). 
rivalizaram com seus vizinhos em matanças e extermínio do inimigo" - de certo modo o tratamento do 'gentio' até hoje permaneceria amparado pela visão da proteção do 'povo eleito'.

27. Tratados foram celebrados e guerras foram travadas também pelos judeus antigos: existem registros de tratados celebrados por Davi, Salomão e subsequentes reis com os estados vizinhos (exceto em relação às sete nações, que tinham sido marcadas para serem exterminadas). E, como em qualquer tempo e lugar, é difícil ordenar sistema de convivência internacional, quando predominam 'interesse nacional' e 'visão nacional': para qualquer sociedade esse risco existe, mas pode ser agravado pelo fundamentalismo, que nega o outro.

Esta não é a única corrente a ser considerada, quer histórica, quer atualmente, como, por exemplo, no livro de Ester: «Os judeus feriram todos os seus inimigos à espada, matando-os e destruindo-os e fizeram o que quiseram com eles» (ESTER 9.5).

Mas, existia igualmente a vertente de aceitação do estrangeiro. Como lembrava Irineu Strenger $(2000)^{46}$ "no Deuteronômio existiam elementos que permitiam a admissão do estrangeiro no convívio com os hebreus e pregavam a mesma solução em tese, para outros povos".

28. A internacionalidade foi dado muito presente no Império persa antigo. As relações entre centro e periferia manifestam-se em setores variados, como na composição dos exércitos dos grandes impérios - e notadamente no persa antigo, onde o comando supremo estava nas mãos do Grande rei, dos membros da família real, dos grandes nobres (persas) da corte, dos sátrapas e alguns corpos de elite, como os famosos "dez mil imortais", mas a massa do exército e os comandos subalternos eram pluriétnicos: representavam todos os povos do império, com suas vestes e uniformes nacionais, suas próprias armas e equipamentos tradicionais. ${ }^{47}$

O catálogo em Heródoto, História ${ }^{48}$ do grande exército de Xerxes oferece “descrição (grega) pitoresca deste amálgama multiforme de povos, vestes e armas”. Em tempo normal, o exército imperial persa não existe como tal; existem divisões locais: ao final do tempo de serviço, as guarnições se transformavam, eventualmente em colônias estáveis de veteranos.

Em casos de crise e de conflito entre centro e periferia, as guarnições provinciais seguiam seus comandos diretos - conflito e negociação se punham interna

46 Irineu Strenger, Direito internacional privado (São Paulo: LTr, 4. ed., rev. e aumentada, 2000).

47 Casella, Direito internacional no tempo antigo (São Paulo: Atlas, 2012, esp. cap. IV. o império persa, p. 233-258).

48 Heródoto, História (trad. do grego, intr. e notas de Mário da Gama Kury, Brasília: Ed UnB, C) 1985, 2. ed., 1988); v. tb. na edição HÉRODOTE - THUCYDIDE. Oeuvres completes (intr. Jacqueline de Romilly, texte présenté, traduit et annoté par André Barguet, Paris: Gallimard - Pleiade, (C) 1964, impr. 1982). 
como externamente, em constante utilização. O exército não era, portanto, um cadinho em que os povos se fundem para formar uma 'nação' homogênea: isso, o exército aquemênida nunca pretendeu conseguir, nem sequer como uma meta ideal, como o exército romano conseguiu realizar na Itália, e mais limitadamente também em algumas províncias.

29. Entre as cidades-estado gregas, como advertia Tucídides (ca. 460- ca. 400 a.C.), na História da guerra do Peloponeso (livro III, 11), ${ }^{49}$

\begin{abstract}
somente o respeito decorrente da igualdade de forças constitui base firme para uma aliança, pois o eventual transgressor recua diante do sentimento de que não tem superioridade bastante para atacar. Não respeitaram a nossa independência senão por lhes ter parecido evidente que, visando ao império, conseguiriam mais facilmente a supremacia com belas palavras e golpes astuciosos de política do que com golpes de força. [...] certamente os aliados em pé de igualdade com eles nunca teriam tomado parte em suas campanhas se os atacantes não fossem culpados de alguma injustiça; de outro lado, também usaram primeiro os recursos unidos dos mais fortes contra os menos porderosos, e deixando os mais fortes para o fim, calcularam que os achariam enfraquecidos quando todos os outros houvessem caído.
\end{abstract}

30. Diversos institutos de direito internacional estavam presentes e eram aplicados entre os antigos gregos: o fracionamento político e a constante oscilação entre guerras e alianças tornam muito presentes e constantes as - hoje chamadas - 'relações internacionais' entre as diversas cidades-estado (pólis) gregas da Antiguidade: vivência nem sempre demonstrada de modo edificante, porque as constantes rivalidades e conflitos entre as cidades-estado helênicas enfraqueceram o conjunto. ${ }^{50}$

Como mostra a análise de Tucídides (ca. 460 - ca. 400 a.C.), ${ }^{51}$ sobre a guerra do Peloponeso, que se estendeu de 431 a 404 a.C., "suas várias cidades careciam de ousadia, atuando separadamente”.

Existem, contudo, evidências de utilização constante de institutos e mecanismos do que, hoje, denominaríamos 'direito internacional', tais como tratados, alianças defensivas e ofensivas, a utilização da arbitragem, para a solução de controvérsias

\footnotetext{
49 Tucídides, História da guerra do Peloponeso (trad. do grego, intr. e notas, Mário da Gama Kury, Brasília: Ed. UnB, (C) 1982, 3. ed., 1987, livro III, 11).

50 Casella, Direito internacional no tempo antigo (São Paulo: Atlas, 2012, esp. cap. V. as cidades estado gregas, p. 259-301).

51 Tucídides, História da guerra do Peloponeso (trad. do grego, intr. e notas, Mário da Gama Kury, Brasília: Ed. UnB, (C) 1982, 3. ed., 1987).
} 
entre cidades estado, tratados de reconhecimento de direitos civis e políticos entre cidades (sympoliteia) e observância do direito de asilo (asylon). ${ }^{52}$

31. Entre o direito e a força, podem os homens oscilar em qualquer tempo e lugar. E, cumpre notar, que a hesitação entre a força (conflito) e o diálogo (negociação) não se dará por virtude, mas por interesse: na medida em que uma potência, aspirante ao império, se sinta apta o bastante, estará mais disposta a usar golpes de força, do que a recorrer às belas palavras e golpes astuciosos de política, para a consecução de sua hegemonia - isso se deu no passado como ocorre reiteradamente em nosso tempo.

A ideia de que somente o respeito decorrente da igualdade de forças constitui base firme para uma aliança ainda foi a base de ordenação do sistema do direito internacional 'clássico', como do “concerto europeu” (1814-1914), e como se deu, também, em tempos mais recentes, no contexto da guerra fria (1949-1989). Esses modelos são puro Tucídides, que - há dois mil e quatrocentos anos -, formulou as premissas muito mais e muito antes dos supostos teóricos 'realistas' das relações internacionais. Estes, como se vê, pouco inovam conceitual e operacionalmente, ao falar no papel da ameaça e do uso da força.

32. A atualidade e a permanência do direito internacional ficam demonstradas, porquanto a grande questão para as civilizações antigas - como para as atuais - permanece presente: até que ponto se constrói sistema relacional com outras potências, ou se vai tentar instaurar regime de hegemonia e de dominação pela força: ‘negociação' e ‘conflito'.

Este dilema permanece presente: basta substituir nomes, para nos darmos conta de quanto serão semelhantes os conteúdos, e é lição adicional para se enfatizar a necessidade de construção e de aperfeiçoamento de sistema institucional e normativo internacional, apto a enfrentar as necessidades decorrentes da crescente interdependência de todos, no contexto pós-moderno.

33. O direito internacional se fez igualmente presente na formação e no desenvolvimento de Roma. Como expunha Cícero (106-43 a.C.), no seu livro De officiis (I.16.51), ${ }^{53}$ esta sociedade, na sua máxima extensão, aberta a todos, une os homens enquanto homens, e todos os povos; nela se deve manter a comunidade de todas as coisas que a natureza criou para uso comum dos homens: «Ac latissime quidem patens hominibus inter ipsos, omnibus inter omnes societas haec est».

\footnotetext{
52 Como mencionado em Casella, Direito internacional no tempo antigo (São Paulo: Atlas, 2012, cap. V. as cidades estado gregas, p. 259-301) a respeito dos institutos de direito internacional, praticados entre as cidades estado gregas na Antiguidade.

53 Cícero, De officiis (edição bilingue, with an English translation by Walter Miller, Cambridge, Ma. / London: Harvard UP / LCL 30, obras de Cícero, v. XXI, (c) 1913, reprinted 2005).
} 
A constituição republicana romana, considera V. Arangio-Ruiz, em sua Storia del diritto romano (ed. 1977), ${ }^{54}$ aparece ainda hoje dentre as obras mais admiráveis da civilização humana. Dentre os estrangeiros que se admiram com a superioridade das soluções romanas, ainda na Antiguidade, apontou-se a lição do grego Políbio, pela qualidade das instituições.

34. Merece ênfase o caráter abrangente e inclusivo do direito das gentes (jus gentium). A 'internacionalidade' pauta a existência e o funcionamento de Roma, desde a sua gênese. ${ }^{55}$

O primeiro incentivo para ampla reforma do direito privado romano foi dado pelas relações entre romanos e estrangeiros, com a instauração de nova categoria de pretores e o surgimento de sistema jurídico, para regência das relações entre romanos e estrangeiros, com base em direito dos 'povos' ou das 'gentes', o «jus gentium».

Contrariamente a enfoques simplistas, que consideram - apressadamente ausentes as premissas do direito internacional, enfatizo que este se faz presente, enquanto conceito e sistema, na evolução de Roma, e nas relações internacionais desta, ao longo de vários séculos na Antiguidade. ${ }^{56}$ Basta atentar para tais elementos, não somente no sentido clássico de relações quer da República, e depois do Império romano, com outras entidades políticas autônomas, em diversas configurações de alianças (foedera), tratados equitativos e desiguais (pacto aequo, pacto iniquim) - e sobretudo, na ocorrência de elemento internacional na base da formação romana (sabinos e latinos).

Mesmo se o «jus gentium», que se poderia chamar de direito internacional, tem importância menor, em relação à magistral contribuição romana para o direito privado, o vigor e a grandeza únicos do gênio jurídico romano se manifestaram, com secular repercussão, no direito internacional.

54 Vincenzo Arangio-Ruiz, Storia del diritto romano (Napoli: Eugenio Jovene, settima edizione riveduta con note aggiunte, ristampa anastatica, 1977, cap. V, 'L'apogeo della costituzione repubblicana: l'Italia e le prime provincie', p. 82-120, cit. p. 82): "La costituzione repubblicana romana [...] ebbe come è noto il suo splendido meriggio nel III o nel II secolo a. C. La prova della sua solidità fu data dalla resistenza della disciplina cittadina alle guerre esterne più aspre, delle quali basterà ricordare la seconda e la terza samnitica e la seconda punica; la prova della duttilità dall'adattamento ai compiti, assolutamente imprevidibili, che furono imposti alla Città dalla progressiva conquista dell'Italia e delle prime province. La soluzione data dai romani ai problemi fondamentali dell'umana convivenza; la felicità del contemperamento tra la funzione legislativa dei comizi popolari e il governo della magistratura e del Senato, la creazione di una classe dominante in cui le tradizioni di famiglia si confondevano con la storia della Città, e che tuttavia sapeva accogliere nel suo seno gli uomini nuovi capaci di portare alla patria il contributo di una fresca genialità, tutto ciò destava allora l'ammirazione degli stranieri, e appare ancora oggi una fra le opere più mirabili dell'umana civiltà'.

55 Casella, Direito internacional no tempo antigo (São Paulo: Atlas, 2012, esp. cap. VI. na formação e no desenvolvimento de Roma, p. 303-334).

56 Ulteriores e mais detalhadas referências em Casella, Direito internacional no tempo antigo (São Paulo: Atlas, 2012, cap. VI, cit., p. 303-334). 
35. A 'internacionalidade', tal como em nossos tempos se definiria, está presente desde o início da vida romana: o dado é vital para compreensão da identidade romana forjada a partir da fusão de elementos latinos e sabinos. Esse mesmo dado se renova e se expande em séculos da história romana, como no 'sistema de equilíbrio internacional' entre o Império romano e o Império medo-persa, com estados tampão, série de tratados e procedimentos, que hoje diríamos 'internacionais' ${ }^{57}$

Existiu e operou sistema de direito e de relações internacionais durante vários séculos, nos quais Roma foi potência mundial: potência interage, durante séculos com o império persa e mantém fluxos comerciais com a Índia antiga (como mostra a lei suntuária de Augusto).

36. Ao lado da 'missão civilizatória' de Roma, se põe também, em sua história, a questão da violência e da guerra: e este foi problema do qual os Romanos tiveram consciência desde a origem. Aulo Gélio (ca. 123-170 A.D.), nas Noites áticas, ${ }^{58}$ relata "história do povo romano e do povo de Cartago, mostrando serem rivais de quase igual força" (livro X, cap. XXVII) "Historia de populo romano deque populo Poenico, quod pari propemodum vigore fuerint aemuli”.

A noção de guerra justa (iustum bellum) é aquela empreendida segundo as formas do direito, formalmente de acordo com a divindade, assim como as 'núpcias justas' são aquelas que produzem efeitos conformes ao direito, ao estatuto das pessoas esse conceito teve enorme influência sobre séculos futuros.

Os cidadãos, alistados na legião, tornam-se soldados ao prestar juramento solene ao chefe que os recruta: o juramento os sacraliza, tornam-se outros, aos olhos dos deuses, e passam a estar habilitados a matar os inimigos, sem se macularem - porque passam a exercer função (munus) público. Quando os soldados são autorizados pelo chefe a deixar temporariamente o exército, voltam a ser, durante essa ausência, cidadãos comuns.

37. O conceito de guerra justa, como registra Tito Lívio (ca. 64 a.C.-10 A.D.), em passagens da sua História de Roma, ${ }^{59}$ e.g. livro I, 14, é a guerra que teria de ser exercida como resposta a ofensa feita por outros povos, contra os romanos:

Alguns anos mais tarde, embaixadores dos laurentinos foram maltratados por parentes do rei Tácio. Embora os laurentinos apelassem para o direito dos povos, Tácio

\footnotetext{
57 Casella, Direito internacional no tempo antigo (São Paulo: Atlas, 2012, esp. cap. VI. na formação e no desenvolvimento de Roma, p. 303-334).

58 Aulus Gellius, Noctes Atticae (with an English translation by John C. Rolfe, Cambridge, Ma. / Londres: Harvard U. P., LCL 200, Aulus Gellius II, first publ. 1927, reprinted 2006, Livro VI, III.40).

59 TITO LÍVIO. História de Roma (do original Ab Urbe condita Libri, introdução, tradução e notas de Paulo Matos Peixoto, São Paulo: Paumape, 1989, em 6 vols.).
} 
deixou-se levar pela afeição e súplicas dos seus. Com isso, a falta daqueles recaiu sobre ele e um dia, em Lavínio, para onde se dirigira para um sacrifício solene, houve um motim e ele foi assassinado.

Dizem que o acontecimento causou menos pesar a Rômulo do que seria de se esperar, ou porque não houvera lealdade na partilha do poder, ou porque não considerara injusto aquele crime. Seja como for, renunciou à guerra, pelo menos naquela ocasião. Contudo, para expiar a ofensa feita aos embaixadores e o assassínio do rei, renovou o tratado entre Roma e Lavínio. ${ }^{60}$

$\mathrm{O}$ conceito de guerra justa (bellum iustum) se contrapõe à guerra injusta em Tito Lívio, História de Roma (do original Ab Urbe condita Libri). ${ }^{61}$ Cumpre observar que teve longa utilização esse conceito de 'guerra justa' durante séculos.

38. A partir do final da Antiguidade se deu a transmissão dos legados grego e romano. Com algumas curiosas configurações, como o fato de que na 'alta' idade média, o legado romano transita pelas Ilhas britânicas, antes de reflorescer na Europa ocidental, na era carolíngia. De modo semelhante, séculos mais tarde, a assim chamada 'escola platônica' de Cambridge será o elo entre o 'renascimento', que se expandiu a partir da Itália e o movimento romântico alemão, que viria séculos depois - o que serve para mostrar que a 'insularidade' britânica o é menos do que apressadamente se afirma.

Não menos fascinante é acompanhar como o legado grego é transposto, a partir dos pensadores árabes, que durante séculos, vivem e obram em diversos centros de cultura da época, uma comunidade que se estendia de Bagdá até a península ibérica, durante os séculos de ocupação muçulmana. Esse mesmo legado grego que ramifica e se expande entre os povos eslavos, e será marcante na evolução da Rússia, será ainda transportado de Bizâncio para a Europa 'ocidental', quando da queda do Império romano do oriente, em 1453.

Bastam, assim, alguns exemplos para se aferir quanto à transmissão de herança cultural pode repercutir por caminhos nem sempre lineares e atentar para a necessidade de 'negociação' mais do que de 'conflito' entre o assim chamado 'Ocidente' e o mundo muçulmano, porquanto este influenciou decisivamente a história intelectual do 'Ocidente': não somente pelas traduções árabes medievais de Aristóteles, como pelos comentários que se fizeram da obra deste, ou a astronomia partir dos escritores árabes.

\footnotetext{
60 TITO LÍVIO (op. cit., ed. cit., livro I, 14, v. I, p. 38-39).

${ }_{61}$ TITO LÍVIO. História de Roma (do original Ab Urbe condita Libri, introdução, tradução e notas de Paulo Matos Peixoto, São Paulo: Paumape, 1989, em 6 vols.).
} 
Este é o papel dos elos de transmissão civilizacional. Que também tem papel a cumprir no direito internacional pós-moderno.

39. Exemplo do papel de transmissão e circulação intelectual do mundo muçulmano para o Ocidente foi o modo como recebeu o Ocidente o sistema de numeração dito 'arábico', que usamos todos os dias, além de contribuições relevantes para vários outros ramos do conhecimento, criados ou transmitidos pelos árabes. Por meio destes, igualmente, nos veio o legado da filosofia, especialmente dos textos de Aristóteles - primeiro traduzidos do árabe para o latim, e somente mais tarde, passaram a ser conhecidos nos originais gregos - aos quais se somam os comentaristas árabes aos textos do Estagirita. ${ }^{62}$

As grandes reflexões da lavra de intelectuais como Abu Ali al-Husain ibn Abdala Ibn Sina, conhecido no Ocidente como Avicena, ou também Al Farabi, ${ }^{63}$ Al Kindi, IbN Rusd, ou na adaptação latina Averrois, Al Ghazali, que formula doutrina essencial para a evolução do islão.

Lugar de destaque cabe a Ibn Khaldun, com seu monumental 'discurso sobre a história universal' - ${ }^{64}$ pelo qual tenho especial predileção, como contribuições que integram o patrimônio cultural da humanidade.

Estes filósofos - e, pela adoção do termo falsafa, eles mostram a sua filiação à filosofia - são continuadores e herdeiros do pensamento grego, particularmente de Aristóteles, como do Neoplatonismo, e eles tiveram grande impacto sobre a construção do pensamento ocidental renascentista e moderno, e como tal merecem ser lembrados e cultivados como relevantes elos de transmissão civilizacional.

40. O direito das gentes no islão pode ser situado em três períodos de duração desigual de sua evolução histórica e do tratamento da guerra santa: a 'era da expansão', a 'era da interação' e a 'era da coexistência' - para a compreensão de sua evolução. Segundo Gamal Badr (2004), ${ }^{65}$ o direito das gentes islâmico não é parte do dogma do islão, mas

${ }_{62}$ Pauline Koetschet, La philosophie arabe - IX $\mathrm{I}^{\mathrm{e}}-\mathrm{XIV}^{\mathrm{e}}$ siècle (textes choisis et présentés par Pauline Koetschet, Paris: Points, 2011, 'introduction', p. 9-31, esp. 'Falsafa et philosophie grecque: les enjeux de la transmission', p. 11-14) assinala que o coração do legado grego, da imensa maioria dos textos gregos, disponíveis no Império bizantino, foi constituído pela quase integralidade da obra do 'primeiro mestre', Aristóteles, e de seus comentadores como Alexandre de Afrodísia e Temístio, enquanto Platão foi transmitido de maneira mais fragmentária.

${ }^{63}$ AL-FARABI. La philosophie de Platon: ses parties, l'ordre de ses parties, du commencement jusqu'à la fin (trad. de l'arabe et annoté par Olivier Sedeyn et Nassim Lévy, Paris: Allia, 2013); ver tb. AL-FARABI. De l'obtention du bonheur (do original Tahsil al-saâda, trad. de l'arabe para Olivier Sedeyn et Nassim Lévy, presenté et annoté par Olivier Sedeyn, Paris: Allia, 2010).

${ }^{64}$ Ibn Khaldun, Discours sur l'histoire universelle (do original Al-Muqaddima, ed. francesa, traduction nouvelle, préf. et. notes V. Monteil, Paris: Sindbad, 3 vols., 1978).

${ }_{65}$ Gamal M. Badr, A Survey of Islamic International Law (in Religion and international law, ed. Mark W. Janis e Carolyn Evans, Leiden: M. Sijthoff, 2004, p. 95-101). 
foi o produto de processo contínuo, de especulação jurídica, por autoridades jurídicas, ao longo dos tempos. O direito das gentes islâmico tem de ser compreendido como parte do conjunto (corpus) do direito islâmico, assim como o jus gentium original era parte do direito interno romano antigo.

Na primeira fase do islão, essa 'era da expansão', que teria durado pouco mais de um século e se pautado pela ideia de religião de vocação universal, com vistas a conquistar o mundo inteiro para a nova fé, onde existem, simultaneamente elementos de ruptura e de continuidade, refere C. Mallat (2011). ${ }^{66}$

$\mathrm{O}$ direito islâmico chegou por último (latecomer), e se o mero fato majoritário das populações atualmente vivendo na área é evidência de sua centralidade, a expansão do islão chegou por último na história das civilizações do Oriente médio. A emergência do Islão, no início do século VII, período conhecido pelos estudiosos ocidentais como 'Antiguidade tardia' ou como 'Alta idade média', parece tanto ruptura radical em relação às tradições jurídicas precedentes, ${ }^{67}$ como continuidade de padrões do Oriente médio, enraizados nas primeiras civilizações, com uso da escrita, e persistem algumas formas até hoje.

41. Dentre as teorias sobre as formas de convivência possível com os não muçulmanos, a formulação inicial da teoria islâmica pelos juristas da primeira época de expansão se punha no sentido de que fora do domínio do islão (dar-al-islam), o resto do mundo se viu chamado coletivamente de território da guerra (dar-al-harb): a relação normal entre este e o estado islâmico seriam a guerra de conquista e a busca da dominação. Nessa visão, as tréguas eram permitidas, mas a duração destas não poderia exceder dez anos, segundo precedente estipulado durante o tempo de vida do profeta.

O fim dessa primeira era decorreu da percepção da impossibilidade de levar o islão aos quatro cantos do mundo: a realidade da interação com potências não muçulmanas impôs novas formulações jurídicas (al-Siyar) com M. Al Shaybani, na configuração de assim chamado 'espaço de convivência' ${ }^{68}$

${ }_{66}$ Chibli Mallat, Introduction to Middle Eastern Law (Oxford: Univ. Press, orig. publicado, 2007, reprinted 2011).

67 Conforme a tese do historiador belga, Henri Pirenne, Mahomet et Charlemagne (1936), segundo o qual a grande 'ruptura' no Ocidente decorreria não das invasões bárbaras, nos séculos IV e V, mas da conquista islâmica no século VII. Esse relevante ensaio de Pirenne teve reedição, seguido de textos de Bruce Lyon, le débat historique sur la fin du monde antique et le début du moyen âge, André Guillou, Byzance et la genèse de l'europe occidentale, Francesco Gabrieli, Effets et influences de l'Islam sur l'europe occidentale, Heiko Steuer, De Théodoric le grand à Charlemagne (trad. de Hélène Seyrès, Milão: Jaca Book, (C) 1986, $1^{\mathrm{a}}$ ed. francesa, 1987); ver tb. H. Pirenne, Les villes du Moyen Âge (Paris: PUF, 1971).

68 Mashood A. Baderin, Muhammad Al-Shaybani (749/50-805) (in The Oxford handbook of the history of international law, edited by B. Fassbender e Anne Peters, Oxford: Univ. Press, 2012, p. 1.081-1.085). 
42. A guerra justa, como conceito herdado dos antigos romanos, tem de ser situada entre guerra santa (jihad) e as 'cruzadas' ${ }^{69}$ na fundamentação para a guerra com os não muçulmanos se considerou, durante a primeira 'era de expansão', que a guerra contra os infiéis era justificada simplesmente por serem estes não muçulmanos. Ainda juristas posteriores enfatizaram a hostilidade em relação e a guerra contra o islão como razão para a guerra santa (jihad).

Quando realidades históricas provaram a futilidade de fazer guerra permanente contra os infieis, o pensamento jurídico reinterpretou o dever da jihad, como 'guerra defensiva', contra aqueles infiéis que ameaçavam o território do islão - a dicotomia entre o território do islão (dar-al-islam) e o território da guerra (dar-al-harb) deu lugar a nova divisão tripartite do mundo. Em lugar da anterior contraposição binária, entre a dar-al-islam e a dar-al-harb, passa a ser apontada a necessidade de categoria nova, a dar-al-sulh, ou seja, o território do compromisso ou dos pactos, que compreendia aqueles outros estados que, embora não reconhecendo a autoridade do estado muçulmano sobre eles, não eram hostis e mantinham com este relações amigáveis - aí se põe a ordenação da 'negociação', ante a impossibilidade de se valer somente do 'conflito'.

43. Ao considerar a guerra e o direito da guerra medieval, ${ }^{70}$ é preciso apontar que o conceito de guerra e o direito de guerra na Idade média provém de três fontes:

- $\quad$ tradição antiga, sobretudo a guerra justa (bellum justum) transmitida pelos romanos; ${ }^{71}$

- tradição da igreja, sobretudo na reinterpretação da doutrina romana antiga da guerra justa, de longo uso;

- direito de legítima defesa, no contexto feudal e da cavalaria, integra de modo essencial o contexto medieval - nesse tempo histórico e nesse contexto cultural, a 'legítima defesa' é vista não como aplicação voluntária de recurso à força, mas como forma de implementação de direito. ${ }^{72}$

69 Casella, Direito internacional no tempo medieval e moderno até Vitória (São Paulo: Atlas, 2012, cap. XI. tratadistas da guerra: Balthazar Ayala e Pierino Belli, p. 245-379, esp. item 11.2 - 'guerra justa e guerra santa: entre jihad e as cruzadas', p. 273-284). Ver tb. Steven Runciman, História das Cruzadas (do original A History of the Crusades (C) 1951, trad. Cristiana de Assis Serra, Rio de Janeiro: Imago, 2002, em 3 vols.: v. I. a primeira cruzada e a fundação do reino de Jerusalém; v. II. cruzadas do século XII; v. III. o reino de Acre e as últimas cruzadas).

70 Casella, Direito internacional no tempo medieval e moderno até Vitória (São Paulo: Atlas, 2012, cap. XI. tratadistas da guerra: Balthazar Ayala e Pierino Belli, p. 245-379, esp. item 11.1 - 'cristianizar a guerra?', p. 265-273).

71 Christian Nadeau e Julie Saada-Gendron, Guerre juste, guerre injuste: histoire, théories et critiques (Paris: PUF, 2009).

72 O que é consentâneo com o direito internacional vigente, como estipula a Carta da Organização das Nações Unidas, de 1945, em seu art. 51: "Nada na presente Carta prejudicará o direito inerente de legítima defesa individual ou coletiva no caso de ocorrer um ataque armado contra um membro das Nações Unidas, até que 
44. Curiosa, se não tortuosa, foi a passagem da 'guerra justa' até se chegar à formulação do que poderia ser uma 'guerra santa' entre os cristãos. ${ }^{73}$ Da tradição inicialmente pacifista da igreja primitiva, se passa a aceitar a 'legitimidade' do conflito armado, sobretudo com a doutrina da guerra 'justa'. Mais do que mudança radical, faz-se revolução doutrinária, ${ }^{74}$ e se vem declarar, com o papa Urbano II (papa de 1088 a 1099), na sua conclamação à cruzada, no final do século XI, o conceito de 'guerra santa', com profundas consequências, não somente no âmbito interno da cristandade, mas também nas relações entre o bloco cristão e o muçulmano, nos séculos transcorridos desde então.

As 'cruzadas', alegadamente 'guerra santa' para os cristãos, ${ }^{75}$ foram agressões imotivadas para os dirigentes muçulmanos da época - ${ }^{76}$ que geraram profundos e duradouros ressentimentos, e esses dados não devem nem podem ser esquecidos, quando se quer compreender as profundas incompreensões que marcam o quadro atual. $\mathrm{O}$ movimento das 'cruzadas' não surge de modo isolado: como tantos fenômenos humanos, sua compreensão exige contextualização, na confluência de fatores vários.

45. Exemplo notório da alternância entre 'negociação' e 'conflito', é preciso contextualizar as cruzadas:

- os árabes, como os bizantinos, eram também herdeiros da civilização grecoromana e os respectivos modos de vida não eram tão distintos assim;

- exceto em raras ocasiões de crises e represálias, as autoridades do Império romano do Oriente (ou Bizâncio) e as do Califado concordavam em não impingir conversões de nenhum dos lados, concedendo liberdade de culto à outra religião;

- os cristãos ‘ocidentais’ não podiam partilhar da tolerância e sensação de segurança

o Conselho de Segurança tenha tomado as medidas necessárias para a manutenção da paz e da segurança internacionais".

73 Casella, Direito internacional no tempo medieval e moderno até Vitória (São Paulo: Atlas, 2012, cap. XI. tratadistas da guerra: Balthazar Ayala e Pierino Belli, p. 245-379, esp. item 11.2 - 'guerra justa e guerra santa: entre jihad e as cruzadas', p. 273-284). Ver tb. os textos de época, reunidos na coletânea de Rolf H. Foerster (hrsg), Die idee Europa: 1300-1946: quellen zur geschichte der politischen einigung (Munique: DTV, 1963).

74 Jean Flori, Guerre sainte, jihad, croisade: violence et religion dans le christianisme et l'islam (Paris: Seuil, 2002, 'Introduction', p. 7-11, cit. p. 7): «l'attitude de l'église chrétienne face à la guerre a, au cours de ces onze siècles, connu une évolution si profonde, un changement si radical, qu'il vaudrait mieux parler à son propos de révolution doctrinale».

75 Extensa e abrangente a análise desenvolvida por Steven Runciman, em sua já referida obra, História das Cruzadas (do original A History of the Crusades (C) 1951, trad. Cristiana de Assis Serra, Rio de Janeiro: Imago, 2002, em 3 vols.: v. I. a primeira cruzada e a fundação do reino de Jerusalém; v. II. cruzadas do século XII; v. III. o reino de Acre e as últimas cruzadas).

76 Instigante o ensaio de Amin Maalouf, Les croisades vues par les arabes (originalmente publicado em 1983, Paris: J'ai lu, 1988, 'avant propos', p. 5): «Ce livre part d'une idée simple: racconter l'histoire des croisades, telles qu'elles ont été vues, vécues et rélatées dans 'l'autre camp', c'est-à-dire du coté arabe. Son contenu repose, à peu près exclusivement, sur les témoignages des historiens et chroniqueurs arabes de l'époque». 
dos cristãos 'bizantinos': estes sentiam orgulho por serem cristãos e herdeiros de Roma, como acreditavam, mas tinham a desconfortável consciência de que, sob muitos aspectos, a civilização muçulmana era superior à sua.

- no movimento ocidental das cruzadas houve influência relevante de dados que não devem ser esquecidos: o jogo de poder e os interesses comerciais;

- o jogo de poder - centralizar e direcionar contra inimigos externos a 'cristandade' ocidental, sob a égide do papado, que teria, ademais, formulada a pretensão de suzerania sobre os territórios conquistados no Oriente médio, conjugado com a manobra diversionista - ante a recorrência da prática e a dificuldade de exercer controle sobre os conflitos do interior da Europa, direcioná-los contra inimigos externos, ademais 'infiéis', como também,

- os interesses comerciais - estabelecer rotas de comércio entre o Oriente médio para a Europa, sem necessidade de intermediação bizantina -, tudo isso e muitos outros dados, ao lado do propósito declarado de "libertar os lugares santos do cristianismo do jugo infiel".

Hoje sabemos quanto é preciso desconfiar desta palavra tão auspiciosa, ‘libertação': pode ser usada em sentidos substancialmente diversos, conforme se trate de conjugá-la com 'negociação' ou com ‘conflito'.

46. A base legal e religiosa para a guerra parte da afirmação de que a guerra pode ser justa (bellum iustum), se declarada por quem tem autoridade para tanto, e desencadeada por 'motivo justo'. Esta pode sofrer valorização adicional, quando a guerra, em alguns casos, pode ser declarada 'santa'. ${ }^{77}$

Como observa Runciman: "a sociedade militar que emergira no Ocidente, em decorrência das invasões bárbaras inevitavelmente procurava justificar o seu passatempo habitual. [...] A guerra santa, quer dizer, a guerra que era do interesse da igreja, tornou-se lícita e até desejável”. ${ }^{78}$

Dentre os precursores do 'direito da guerra', em meados do século IX, o papa Leão IV (847-855) declarou que todos os que morressem em batalha, em defesa da igreja, receberiam uma recompensa celestial.

77 Como se examina em Casella, Direito internacional no tempo medieval e moderno até Vitória (São Paulo: Atlas, 2012, cap. XI. tratadistas da guerra: Balthazar Ayala e Pierino Belli, p. 245-379, esp. item 11.2 'guerra justa e guerra santa: entre jihad e as cruzadas', p. 273-284).

78 S. Runciman (op. cit., 1951, ed. bras., 2002, v. I, cit. p. 84): “O código de cavalaria que se desenvolvia, apoiado por épicos populares, prestigiava o herói militar; e o pacifista adquiriu uma má reputação, da qual nunca mais se recuperou. Contra tal sentimento, a igreja pouco podia fazer. Procurou, em vez disso, direcionar a energia belicosa de modo que revertesse em sua vantagem". 
Nicolau I Magno (papa 858-867) foi contemporâneo do patriarca ortodoxo Metódio. ${ }^{79}$ Engajado nas lutas entre império e papado, como na confrontação entre Roma e Bizâncio, teve a sua formulação da doutrina da guerra na famosa Carta aos búlgaros. Nicolau I determinou que os homens sob sentença da igreja por seus pecados não deveriam portar armas, exceto para combater os infiéis. ${ }^{80}$

Algumas décadas mais tarde, João VIII (papa 872-882), classificou as vítimas de uma guerra santa como mártires; e caso morressem em batalha, teriam os seus pecados remidos. O soldado, porém, deveria ser puro de coração.

47. A guerra contra os muçulmanos na Espanha adquiriu o status de guerra santa. Em 1063, o rei de Aragão, Ramiro I, que lançara grande ofensiva contra os muçulmanos, foi assassinado por um muçulmano em Grados. Essa morte teve efeito catalisador sobre parte da Europa.

Em resposta, Alexandre II (papa 1061-1073) conclama à luta pela cruz, na Espanha, e promete indulgência a todos os que nesta luta se empenhassem. O que leva à reunião de um exército para levar adiante a obra de Ramiro. ${ }^{81}$

Seu sucessor, Gregório VII (papa 1073-1085) convida os príncipes da cristandade a ingressar no movimento pela recuperação da Espanha. Ao mesmo tempo, com base na falsificação da Doação de Constantino, lembrava ao mundo que a Espanha integrava o domínio de São Pedro, e declarava que os cavaleiros cristãos poderiam tomar posse das terras que conquistassem aos infiéis. ${ }^{82}$

Os castelhanos capturam Toledo, em 1085. Segue-se a retomada islâmica, sob condução dos mais fanáticos almorávidas. Assim, a partir de 1087, os cavaleiros cristãos foram convocados com urgência à Espanha para arrostá-los.

Urbano II (papa 1088-1099) dá apoio às lutas dos cristãos na Espanha. Até o fim do século, "as campanhas espanholas continuaram atraindo cavaleiros cristãos

79 Ver Casella, Direito internacional no tempo medieval e moderno até Vitória (São Paulo: Atlas, 2012, no item introdutório, 'caminhos da instauração medieval'). Veja-se Anthony-Emil N. Tachiaos, Cirillo e Metodio: le radici cristiane della cultura slava (do original Cyril and Methodius of Thessalonica: the acculturation of the Slavs (C) 2001, ed. italiana a cura di Marcello Garzaniti, Milão: Jaca Book, 2005, esp. cap. 8, 'L'attività dei discepoli in Bulgaria', p. 119-131).

80 Carta de Nicolau I em Monumenta Germaniae Historica: Epistolae (v. VI, p. 658). Essa carta foi incorporada às Decretais de Graciano, no século XII. O que seria indício de sua aceitação como conteúdo, pela doutrina oficial da igreja.

81 S. Runciman (op. cit., 1951, ed. bras., 2002, v. I, cit. p. 89): “iniciou-se um afluxo de cavaleiros franceses que atravessaram os Pirineus para continuar o trabalho. Em 1073, uma nova expedição foi organizada por Ebles de Roucy".

82 S. Runciman (op. cit., 1951, ed. bras., 2002, v. I, cit. p. 89): “Em 1078, Hugo I, duque da Burgúndia [Borgonha], liderou um exército para ajudar seu cunhado, Alfonso VI, de Castela. Em 1080, Gregório VII estimulou pessoalmente uma expedição comandada por Guy-Geoffrey. Durante os anos seguintes, tudo correu bem". 
aventureiros do norte, até que a captura de Huesca, em 1096, e de Barbastro, em 1101, marcou o fim dessa série de campanhas". ${ }^{83}$ A mudança conceitual estava feita.

48. No final do século XI, a ideia da guerra santa, portanto, fora posta em prática: os cavaleiros e os soldados cristãos foram incentivados, pelas autoridades eclesiásticas, a deixar suas querelas mesquinhas e partir para as fronteiras da cristandade, para combater os infiéis. A recompensa por seus serviços seria a posse das terras que conquistassem, além de benefícios espirituais. Quais seriam exatamente tais benefícios é algo que não se sabe ao certo. Aos poucos, o pontificado assumiu a direção das guerras santas. Em geral, era o responsável por lançá-las e selecionar seu comandante. A terra conquistada encontrava-se, em última instância, sob suserania papal. ${ }^{84}$

A valorização da guerra claramente se põe, desde o início no islão, como política de expansão da fé, com uso da força armada (jihad). Alguns séculos mais tarde, os cristãos tomam emprestado do Islão o conceito de santidade da guerra - o que conferia à guerra e ao guerreiro diversos benefícios neste mundo e no outro.

A partir da já mencionada conclamação à primeira cruzada, pelo papa Urbano II, em 1095, passa a ocorrer, por vezes com desenvolvimento tortuosos, o status elevado conferido à guerra e ao guerreiro passa a valer também no âmbito do Cristianismo. Em continuação ao antes ocorrido, na Espanha, com a conclamação à luta pela reconquista do território.

A luta para a 'reconquista' desse território, al-andaluz, há séculos ocupado pelos muçulmanos, foi declarada 'guerra santa' dos cristãos - embora, logicamente, o 'outro lado' parecia ver as coisas de modo diverso. A civilização árabe muçulmana da Espanha foi grande centro intelectual, lugar de encontro e diálogo entre culturas, cuja duração se estende por quase oito séculos, desde o início da ocupação muçulmana, a partir de 711, até a 'reconquista' pelos reis católicos, em $1492 .{ }^{85}$

49. Como em relação a outras coisas na história e no direito, é curioso apreciar como se deu o que poderia ser chamada a 'construção legal' das cruzadas:

- na construção do direito internacional cabe determinar a base conceitual, sobre a qual este há de ser estruturado: será laica, e terá por base a afirmação intrínseca da dignidade humana, enquanto tal, ou terá laivos, mais ou menos marcados, de base confessional, e estes podem nos levar aos modelos ideológicos de confronto, disfarçados de conflito entre civilizações, para ‘aniquilar os gentios', nos fundamentalismos religiosos, e aí corre-se o risco de retomar as concepções

\footnotetext{
83 S. Runciman (op. cit., 1951, ed. bras., 2002, v. I, cit. p. 90).

${ }^{84}$ S. Runciman (op. cit., 1951, ed. bras., 2002, v. I, cit. p. 90).

85 A respeito, ver AL-ANDALUS: Anthologie (trad. et présentation par Brigitte Foulon et Emmanuelle Tixier du Mesnil, Paris: Flammarion, 2009).
} 
de guerra santa, jihad ou cruzada;

- ao descrever a evolução das ideias, das mentalidades e das atitudes das duas religiões em relação à guerra, percebe-se que o nascimento da guerra dita santa no Ocidente interage com a ideia de jihad islâmica - a 'negociação' e o 'conflito' entre dois mundos;

- culmina na conclamação à cruzada, como ataque frontal e direto ao islamismo, colocado diante do Ocidente, e foi a dramática etapa final dessa transformação que se estende por um milênio, partindo do pacifismo essencial do cristianismo original (“dar a outra face"), e que repercute no avanço islâmico sobre a Europa até quase as portas de Viena, ainda no século XVII.

50. É interessante contrapor as visões islâmica e cristã da guerra: contrariamente à mutação radical ocorrida no cristianismo, no caso do islamismo não ocorre mudança tão significativa, mas lenta acomodação, para acolher uma terceira e nova categoria de relação com os não muçulmanos - em espaço da convivência organizada. Existe, ademais, atitude fundamentalmente diversa entre os dois fundadores dessas religiões, em relação ao uso da força armada e da guerra: o profeta Muhammad - ou Maomé, na grafia incorreta, porém de uso corrente no Ocidente - desde o início, não repudia o uso da violência e aceita a guerra santa (jihad), o que seus sucessores ampliam, não somente como aspecto intrínseco dos deveres do fiel, como estendem ao conjunto do mundo seu âmbito de aplicação.

As conquistas árabes dos séculos VIII e IX se fazem em nome da fé muçulmana, são realizadas em detrimento do Império romano do oriente e dos reinos cristãos que se encontraram no caminho dos guerreiros de Alá: mas, apesar da rapidez e da violência do avanço, isso se fez sem deixar de manter certa tolerância e aceitação - mediante o pagamento de tributo e mantendo os infiéis em situação subordinada - em relação aos cristãos e os judeus, como as "religiões do livro", nos territórios conquistados pelo islão - os não muçulmanos pagavam tributos e não podiam portar armas.

51. A aceitação da guerra e mesmo a tentativa de 'sacralização' da guerra passa por fases de evolução totalmente distintas, se comparamos os mundos cristão e muçulmano. Ocorre profunda mudança no tratamento da guerra: a 'revolução doutrinária', no seio do cristianismo, levou à elaboração da 'guerra santa', retomando muitos elementos do jihad islâmico. ${ }^{86}$

86 Casella, Direito internacional no tempo medieval e moderno até Vitória (São Paulo: Atlas, 2012, cap. XI. tratadistas da guerra: Balthazar Ayala e Pierino Belli, p. 245-379, esp. item 11.2 - 'guerra justa e guerra santa: entre jihad e as cruzadas', p. 273-284). 
Claramente as duas religiões monoteístas tinham chegado, nessa mesma altura - fim do século XI - a nível similar de 'sacralização' da guerra, com nefasto impacto para o futuro da convivência - se o 'conflito' é sagrado, diminui o espaço possível para o exercício de 'negociação'. Sobretudo no lado ocidental, a herança medieval dos ideais da 'cavalaria', ${ }^{87}$ ou mesmo “o peso do passado' da herança da 'guerra justa', poderia parecer considerável, mas cujo impacto se faz sentir em menor grau, do que ocorreria para o lado muçulmano.

Esses desenvolvimentos geram distorções e são fonte de incompreensão entre esses dois mundos paralelos. Depois de mil e trezentos anos, cristãos e muçulmanos, em lugar de caminhar para o entendimento e a convivência organizada - por meio da 'negociação' - estão mais do que nunca, em nossos tempos, em plena utilização do 'conflito', como meio habitual de relacionamento. Com tensões recorrentes e enormes prejuízos, para ambos os lados.

52. Em outro quadrante do mundo, na relação entre dois grandes impérios, a alternância de 'negociação' e de ‘conflito', entre russos e chineses, não trouxe somente a paz, como também levou à difusão do uso do chá entre os russos. ${ }^{88} \mathrm{E}$ isso se fez há vários séculos, a partir de incidente que poderia ter sido encaminhado para o 'conflito', mas onde prevaleceu a 'negociação'.

Em 1689 estabeleceu-se o padrão de convivência, que nortearia as relações entre os dois povos durante duzentos anos: como a fronteira entre os Impérios chinês e russo foi estabelecida no rio Amur, no final do século XVII, é relatado por Voltaire, na sua História do império da Rússia sob Pedro, o grande (1760-1762). ${ }^{89}$

Nesse período do 'direito internacional clássico', entre meados do século XVII até meados do século XVIII, enquanto a Europa, dita civilizada, estava mergulhada em infindáveis guerras, as relações entre esses dois grandes impérios, o russo e o chinês, se alinhou pela solução pacífica de controvérsias. Os russos e os chineses, em seus respectivos processos de expansão territorial, chegaram a ter contato uns com os outros, ao longo do rio Amur. Os russos, vindos do Norte, e os chineses, procurando solos adequados para a

87 Ver, a respeito dos ideais da cavalaria medieval, do historiador holandês Johan Huizinga, La valeur politique et militaire des idées de chevalerie à la fin du Moyen Âge (Revue d'Histoire Diplomatique, publiée par les soins de la Société d'histoire diplomatique, Paris: Plon [Librairie Plon-Nourrit et Cie., Imprimeurs Éditeurs], 35 $5^{\mathrm{e}}$ année, 1921, p. 126-138); compare-se a análise de Marc Bloch, Liberté et servitude personnelles au Moyen Age, particulièrement en France - contribution à une étude des classes (originalmente publicado em 1933, in M. Bloch, Mélanges historiques, Paris: Ed. CNRS, 2011, p. 286-355).

88 Como se examina em Casella, BRICS - Brazil, Russia, India, China and South Africa: the present picture and perspectives (ministrado em agosto de 2015 no XLII Curso de direito internacional, e publicado em Washington: OEA - Comité Jurídico Interamericano, 2016, no prelo).

89 Voltaire, Histoire de l'empire de Russie sous Pierre le grand, divisée en deux parties (1760-1762, in Voltaire, Oeuvres historiques, édition présentée, établie et annotée par René Pomeau, Paris: Gallimard - Pleiade, (C) 1957, impr. 2010, p. 337-602). 
agricultura, rumo ao Nordeste, abrindo florestas para a implementação de novas áreas de agricultura na Manchuria.

Esses contatos tiveram, entre outras consequências, o fato de que o chá chinês foi adotado pelos russos, e se tornou costume nacional - para avaliar o impacto disso, basta pensar quantas vezes em romances e contos da literatura russa aparece o samovar com o chá, como local e momento para a bebida quente, como também para a conversação: quão diversa teriam sido a vida e a literatura russas sem o chá, levado da China para a Rússia naquela época?

Russos e chineses, tendo chegado à mesma área, e diante da necessidade de negociação sobre a soberania de cada um na região, assinaram o tratado de Nertchinsk (1689), segundo o qual os chineses asseguraram para si a inteira bacia do rio Amur, e a mantiveram. A fronteira entre a China e a Rússia foi assim fixada pelo rio.

53. Os antigos Impérios russo e chinês conseguiram alcançar solução negociada de controvérsia que opunha essas duas imensas civilizações. Voltaire (17601762, ed. 2010 ${ }^{90}$ mostrou como China e Rússia foram capazes de resolver seu conflito fronteiriço, por meio de negociação:

\begin{abstract}
entre esses dois países, durante tanto tempo desconhecidos, como a China e a Rússia, tinham ocorrido controvérsias sobre as fronteiras de seus respectivos impérios. A Rússia tinha algumas fortificações na margem do rio Amur, a trezentas léguas da Grande Muralha. Tinham ocorrido muitas hostilidades, entre os Chineses e os Russos, por causa dessas fortificações. Finalmente, os dois estados compreenderam como poderiam proteger do melhor modo os seus interesses: o imperador Kang XI preferiu a paz e o comércio, em lugar de uma guerra inútil. Ele enviou seus embaixadores para Nipchou, um destes postos avançados. Esses embaixadores tinham algo como dez mil homens com eles, incluindo os seus séquitos. Isso era a opulência asiática. Mas o mais admirável foi o fato de que não havia qualquer precedente, nos registros da história do Império, de uma embaixada, enviada a outra potência. O que é igualmente único é que os chineses não tinham assinado qualquer tratado de paz, desde a fundação do império.
\end{abstract}

54. Interessante observar como fizeram os russos e os chineses, no século XVII, para conduzir a negociação. Ainda acompanhando Voltaire. ${ }^{91}$ Este também apontou

90 Voltaire, Histoire de l'empire de Russie sous Pierre le grand, divisée en deux parties (1760-1762, in Voltaire, Oeuvres historiques, édition présentée, établie et annotée par René Pomeau, Paris: Gallimard - Pleiade, (C) 1957, impr. 2010, p. 337-602).

91 Voltaire, Histoire de l'empire de Russie sous Pierre le grand (op. cit., 1760-1762, éd. R. Pomeau, Paris: Gallimard - Pleiade, (C) 1957, impr. 2010, p. 337-602). 
como as negociações foram conduzidas e como o tratado foi redigido entre os chineses e os russos, usando o latim como a língua para as negociações e para o registro do entendimento, alcançado entre os dois lados. ${ }^{92}$

Apesar de suas duras críticas contra o que ele via como limitações do Direito Internacional, no tempo clássico, Voltaire também registrou a ocorrência e os efeitos positivos do uso inteligente de mecanismos para a solução pacífica de controvérsias - ele enfatizou a importância do precedente, entre estas duas potências: para Voltaire, Rússia e China tinham assim dado exemplo para as potências europeias da época, engajadas em guerras umas contra as outras. ${ }^{93}$ Essa mesma lição pode ser útil, até os nossos tempos: existe vínculo direto desse precedente histórico com a iniciativa dos BRICS e o papel que esta pode ter não somente entre os participantes, como sobre o conjunto do mundo. ${ }^{94}$

A apreciação das circunstâncias do tratado de Nertchinsk, em 1689, é um tanto mais cética, por parte de Geoffrey Hosking (2012). ${ }^{95}$ Em sua obra sobre a "Rússia e os russos", pondera ter inicialmente sido negligenciada a oferta chinesa de solução da questão pela via diplomática, e que somente após o deslocamento de exército chinês, com efetivo militar em número suficiente para tomar pela força o forte russo de Albazin, em 1685, os russos se dispuseram a negociar: "o território estava simplesmente longe demais, para ser defendido pela Rússia europeia contra adversário, de qualquer tamanho, imbuído de determinação. Além disso, pouco tinham feito os russos para serem estimados pelas populações locais". De tal modo, avalia:

O tratado de Nertchinsk (1689), nota Hosking, representou exatamente o tipo de solução que os russos tinham inicialmente rejeitado: eles tiveram de evacuar toda a bacia

$92 \quad$ Voltaire, Histoire de l'empire de Russie sous Pierre le grand (1760-1762, ed. René Pomeau, Paris: Gallimard - Pleiade, (C) 1957, impr. 2010, p. 337-602): "En quelle langue d'ailleurs les Chinois pouvaient-ils traiter avec les Russes au milieu des déserts? Deux jésuites, l'un portugais, nommé Péreira, l'autre français, nommé Gerbillon, partis de Pékin avec les ambassadeurs chinois, leur aplanirent toutes ces difficultés nouvelles, et furent les véritables médiateurs. Ils traitèrent en latin avec un Allemand de l'ambassade russe, qui savait cette langue. [...] Les deux jésuites réglèrent les limites des deux dominations; elles furent posées à la rivière de Kerbechi, près de l'endroit même où l'on négociait. Le midi resta aux Chinois, le nord aux Russes. Il n'en coûta à ceux-ci qu'une petite forteresse qui se trouva bâtie au delà des limites; on jura une paix éternelle, et, après quelques contestations, les Russes et les Chinois la jurèrent au nom du même Dieu en ces termes: 'Si quelqu'un a jamais la pensée secrète de rallumer le feu de la guerre, nous prions le Seigneur souverain de toutes choses, qui connaît les coeurs, de punir ces traîtres par une mort précipitée"".

93 Voltaire, na sua já referida Histoire de l'empire de Russie sous Pierre le grand, divisée en deux parties (1760-1762, in Voltaire, Oeuvres historiques, éd. René Pomeau, Paris: Gallimard - Pleiade, C 1957, impr. 2010, p. 337-602).

94 Como se examina em Casella, BRICS - Brazil, Russia, India, China and South Africa: the present picture and perspectives (ministrado em agosto de 2015 no XLII Curso de direito internacional, e publicado em Washington: OEA - Comité Jurídico Interamericano, 2016, no prelo).

95 Geoffrey Hosking, Russia and the Russians: from earliest times to the present - (originalmente publicado em 2001, Londres: Penguin, 2nd. ed. "fully updated with a new chapter", 2012). 
do rio Amur, recebendo em troca privilégios comerciais, consistente em rota regular de caravanas, que ingressava na China por Kiakhta, no rio Selenga. Foi estipulado que os chefes das caravanas oficiais deveriam prestar o kowtow (a reverência batendo por três vezes com a testa no chão) diante do imperador chinês. Essa foi a base das relações russo-chinesas durante duzentos anos. ${ }^{96}$

55. Para passar à visão de conjunto, a respeito de cinco mil anos de registro da história, a alternância entre 'negociação' e 'conflito' é questão central dentre os fundamentos do direito internacional pós-moderno:

- como busca de 'discurso revelador e reunificador da polis do tempo' - em que medida podem ser apontados valores e interesses compartilhados, em relação a 'negociação' e a 'conflito'?

- $\quad$ pode-se pensar modelo que seja adequado, para todos os povos do mundo? No conflito ideológico dos tempos da "guerra fria" ou no "conflito de civilizações" foram antes formas de "equilíbrio do terror", onde a multiplicação da capacidade de destruição recíproca obrigava os oponentes ideológicos a manterem determinado nível de contenção autoimposta, na prática de abusos, ou ao menos tentar velar as violações cometidas, sob a aparência de respeito e observância às formas e modelos legais;

- na questão da escolha entre 'negociação' e 'conflito' se põe o discurso do fundamento do direito internacional, como enfrentar a questão do discurso revelador e reunificador da polis do tempo?

- em contraposição a estes debates, atualmente vivemos o conflito decorrente de 'falta de civilização': o enfrentamento não se faz entre 'ocidente' e 'oriente', mas entre modelos com ênfase na civilização e nos valores compartilhados, ou modelos limítrofes de barbárie! Seja qual for a cor destes, e a origem de seus 'programas de ação'.

56. Direcionando as questões suscitadas na presente apresentação, o direito internacional se faz e opera por meio de regulação:

- é este uma ferramenta limitada e falível, mas sempre passível de aperfeiçoamento, como se reconhece e se afirma desde Grócio, na primeira metade do século XVII: este pode ser aperfeiçoado para a mais adequada regulação da vida internacional; ${ }^{97}$

96 G. Hosking, Russia and the Russians: from earliest times to the present (op. cit., 2012, p. 148).

97 A respeito de Hugo Grócio (1583-1645), ver Casella, Direito internacional no tempo moderno de Suarez a Grócio (São Paulo: Atlas, 2014, cap. XVIII, p. 309-587, esp. item 18.7 - 'herança crítica e repercussão da 
- como formular a questão do discurso revelador e reunificador da polis do tempo entre 'negociação' e 'conflito' em relação aos fundamentos do direito internacional? E a partir desta, todas as demais questões relevantes e pertinentes em direito internacional?

- $\quad$ partindo da análise feita, há quase quinhentos anos, por Nicolau Maquiavel, na sua Arte da guerra (1521), ${ }^{98}$ onde este fazia “discurso filosófico" em torno da "arte da guerra" e das técnicas desta - pode-se chegar a esta conclusão: os progressos da tecnologia não adiantaram muito - a guerra incorporou desenvolvimentos tecnológicos, e se fez muito mais mortífera, mas pouco aprenderam os homens quanto aos meios alternativos, para não ter de recorrer a esta forma de enfrentar adversários - e assim permanece central a alternância entre 'negociação' e 'conflito';

- não se sabe nem se pode saber, ainda, quais sejam todos os desafios, nem tampouco foram colocadas todas as questões, mas permanecem a necessidade e a busca de valores e princípios, para a ordenação da convivência organizada entre os homens - a 'negociação' - e mesmo se isso se vem tentando, nos últimos séculos, desde que começa a esboçar-se o que se pode chamar de modelos de convivência internacional institucionalizada, com a aferição do papel do direito internacional na regulação da convivência humana, ainda permanecem enormes extensões não reguladas, nas quais predomina o 'conflito'.

57. O imenso e fascinante tema do direito internacional na história mostra como:

- em alguns breves momentos, parecem ter sido levantadas as barreiras, para permitir o diálogo entre diferentes visões de mundo: esses momentos de 'negociação' em lugar do 'conflito' deixam lições relevantes, para os tempos futuros;

- mais do que meros expedientes técnicos, tanto o direito quanto as relações internacionais, no contexto pós-moderno, precisam conservar essa lição e a missão de diálogo e de percepção do outro: não se poderá pretender criar normas e mecanismos internacionalmente vigentes, e aceitáveis para o conjunto da humanidade, sem levar em conta as diferenças culturais e sem as acomodar em tais regulações, na medida em que possam os homens e as sociedades chegar a conviver de modo pacífico;

obra de Grócio', p. 499-587).

98 Maquiavel, Dell'arte della guerra. In: MACHIAVELLI, Niccolò. Tutte le opere (a cura di Mario Martelli, Firenze: Sansoni, 1971, p. 299-398). 
- a convivência juridicamente organizada entre estados e demais sujeitos de direito internacional não pode prescindir do direito internacional nem do reconhecimento do contexto cultural e das diversidades entre civilizações. Ao mesmo tempo em que notáveis avanços pontuais podem ser apontados, é preciso reconhecer que, institucionalmente, pouco se conseguiu construir, ao longo do tempo, para ordenar esta convivência entre mundos diversos;

- desde a Antiguidade, nos fica a lição, que para se escrever a história, a tarefa mais difícil não é determinar os fatos, mas é crucial compreender a mentalidade de outro povo, como de outras épocas: o mesmo vale para quaisquer relações humanas - é sempre difícil entender as razões do outro, e colocar-se no lugar do outro. Esse é indispensável aprendizado humanista, ${ }^{99}$ a ser exercitado em cada um de nós, como também pelas civilizações, enquanto conjuntos organizados de convivência entre pessoas.

\section{Conclusão}

58. Retomando a lição de Boecio, ${ }^{100}$ em seu testamento intelectual e afirmação do papel do humanismo, para se poder alcançar a regulação da vida internacional - entre 'negociação' e ‘conflito' - é preciso ocorrer a combinação adequada dos dois fatores, como nos apontava: a conjugação da vontade (voluntas) e da potência (potestas) - porquanto uma sem a outra não produzirá resultados.

Também permanece útil e oportuna a lição de Dante, ${ }^{101}$ quando este advertia: como tivemos a vantagem de nos beneficiar dos esforços dos que nos precederam,

99 O humanismo seria vertente central para a compreensão da busca da sabedoria e da compreensão, em diferentes tradições do Ocidente, como aponta Abdennour Bidar, em seu ensaio sobre Histoire de l'humanisme en Occident (Paris: Armin Colin, 2014, cit. p. 14) observa: «il y a dans la civilisation de l'Occident, et probablement dans chaque civilisation un génie propre qui se cristallise en quelques interrogations fondamentales, autour desquelles les intelligences d'une époque se retrouvent, nous précèdent et retrouvent les âmes de ceux qui les ont précédés. [...] J'ai simplement voulu proposer ici au lecteur de parcourir avec moi l'un des plus longs, vieux et vastes chemins de cette civilisation occidentale: celui de ses humanismes».

100 Boécio, La consolation de la philosophie (traduction nouvelle en prose et en vers avec le texte en regard par Louis Judicis de Mirandol, Paris: Guy Trédaniel / Ed. de la Maisnie, 1981, Livro IV, III, p. 210-211); b/c, Boèce, La consolation de la philosophie / Philosophiae consolationis (traduction nouvelle avec une introduction et des notes par Aristide Bocognano, Paris: Garnier, 1937, Livro IV, Prosa 2, p. 158-159) contrapondo a vontade e a potência: «Duo sunt, quibus omnis humanorum actuum constat effectus: voluntas scilicet, ac potestas; quorum si alterutrum desit, nihil est quod explicari queat. Deficiente etenim voluntate, ne agreditur quidem quisque quod non vult; at si potestas absit, voluntas frustra sit».

101 Igualmente referida supra, a lição de Dante Alighieri, no seu De Monarchia (in Tutte le opere, a cura di Luigi Blasucci, Firenze: Sansoni, primeira edição, 1965, quarta edição, 1989, p. 247-316, cit. I.1, p. 250) justamente quando este nos aponta: «Omnium hominum quos ad amorem veritatem natura superior impressit hoc maxime interesse videtur: ut, quemadmodum de labore antiquorum ditati sunt, ita et ipsi 
devemos trabalhar para que a posteridade possa servir-se do fruto de nossos esforços este é o sentido da civilização na história humana. O direito internacional é parte desse legado civilizacional, que se inscreve entre 'negociação' e 'conflito', como ferramenta para a construção e a conservação do legado da civilização.

São Paulo, abril de 2019.

\section{Referências}

AL-ANDALUS: Anthologie. Traduction et présentation par Brigitte Foulon et Emmanuelle Tixier du Mesnil. Paris: Flammarion, 2009.

AL-FARABI. De l'obtention du bonheur. Traduit de l'arabe para Olivier Sedeyn et Nassim Lévy, presenté et annoté par Olivier Sedeyn. Paris: Allia, 2010.

AL-FARABI. La philosophie de Platon: ses parties, l'ordre de ses parties, du commencement jusqu'à la fin. Traduit de l'arabe et annoté par Olivier Sedeyn et Nassim Lévy. Paris: Allia, 2013.

ALIGHIERI, Dante. De Monarchia. In: BLASUCCI, Luigi (ed.). Tutte le opere. Firenze: Sansoni, 1965. p. 247-316.

ARAGON, Louis. Henri Matisse: roman. Paris: Gallimard, 1998.

ARAGON, Louis. Matisse ou la grandeur. In: ARAGON, Louis. Henri Matisse: roman. Paris: Gallimard, 1998. p. 17-27.

ARANGIO-RUIZ, Vincenzo. L'apogeo della costituzione repubblicana: l'Italia e le prime provincie. In: . Storia del diritto romano. Napoli: Eugenio Jovene, 1977. p. 82-120.

ARISTÓTELES. Poética. Tradução, comentários e índices analítico e onomástico de Eudoro de SOUZA. São Paulo: Abril, 1973.

ARISTOTLE. Poetics. Translated by Stephen Halliwell, Cambridge, MA.: Harvard University Press, 1995. Loeb Classical Library 199, Aristotle 23.

BÂ, Amadou Hampâté. Vie et enseignement de Tierno Bokar: le sage de Bandiagara. Paris: Éditions du Seuil, 1980.

BADERIN, Mashood A., Muhammad Al-Shaybani (749/50-805). In: FASSBENDER, Bardo; PETERS, Anne. The Oxford handbook of the history of international law. Oxford: Oxford University Press, 2012. p. 1.081-1.085.

BADR, Gamal M. A survey of Islamic international law. In: JANIS, Mark W.; EVANS, Carolyn (ed.). Religion and international law. Leiden: M. Sijthoff, 2004. p. 95-101.

posteris prolaborent, quatenus ab eis posteritas habeat quo ditetur». 
BERNHARDT, Rudolf. Le règlement judiciaire et arbitral et arbitral des différends internationaux impliquant plus de deux États. Berlin, août 1999. Disponível em: http://www.idi-iil.org/app/ uploads/2017/06/1999_ber_02_fr.pdf.

BIBLIA. Biblia sacra iuxta Vulgatam Clementinam: logicis partitionibus aliisque subsidiis ornata a R. P. Alberto Colunga et Laurentio Turrado. 5. ed. Madri: Biblioteca de Autores Cristianos, 1977. BÍBLIA. Bíblia sagrada: nova versão internacional. São Paulo: Sociedade Bíblica Internacional, 2000 .

BIDAR, Abdennour. Histoire de l'humanisme en Occident. Paris: Armand Colin, 2014.

BLOCH, Marc. Liberté et servitude personnelles au Moyen Âge, particulièrement en France: contribution à une étude des classes. In: BLOCH, Marc. Mélanges historiques. Préface de Yann Potin. Paris: CNRS, 2011. p. 286-355.

BOÈCE. La consolation de la philosophie. Traduction nouvelle avec une introduction et des notes par Aristide Bocognano. Paris: Garnier, 1937.

BOÉCIO. Consolation de la philosophie. Traduction nouvelle en prose et en vers par Louis Judicis de Mirandol. Paris: Guy Trédaniel. Éditions de la Maisnie, 1981.

BOISSON DE CHAZOURNES, Laurence; MEHDI, Rostane (coord.). Une société internationale en mutation: quels acteurs pour une nouvelle gouvernance? Bruxelles: Bruylant, 2005.

BRAUDEL, Fernand. Les écrits de Fernand Braudel: les ambitions de 1'histoire. Paris: Fallois, 1997.

BURCKHARDT, Jacob. Kulturgeschichtliche vorträge. Stuttgart: Alfred Kröner, 1959.

BURKE, Peter. What is cultural history? Cambridge: Polity, 2004.

CASELLA, Paulo Borba. A proteção internacional dos direitos das minorias: o caso da minoria por orientação sexual e identidade de gênero. In: JUBILUT, Liliana Lyra; BAHIA, Alexandre Gustavo Melo Franco; MAGALHÃES, José Luiz Quadros de (coord.). Direito à diferença: aspectos teóricos e conceituais da proteção às minorias e aos grupos vulneráveis. São Paulo: Saraiva, 2013. p. 179188.

CASELLA, Paulo Borba. Abz: ensaios didáticos. São Paulo: Imprensa Oficial do Estado, 2008.

CASELLA, Paulo Borba. BRICS - Brazil, Russia, India, China and South Africa: the present picture and perspectives. In: CURSO DE DERECHO INTERNACIONAL, 42., 2015, Rio de Janeiro. Anais [...]. Washington: OEA, 2015. p. 13-90. Disponível em: http://www.oas.org/es/sla/ddi/docs/ publicaciones_digital_XLII_curso_derecho_internacional_2015_Publicacion_Completa.pdf.

CASELLA, Paulo Borba. Conceito de sistema, contexto internacional e pós-modernidade. In: BITTAR, Eduardo Carlos Bianca; ADEODATO, João Maurício (org.). Filosofia e teoria geral do 
direito: estudos em homenagem a Tércio Sampaio Ferraz Junior por seu septuagésimo aniversário. São Paulo: Quartier Latin, 2011. p. 999-1.024.

CASELLA, Paulo Borba. Direito internacional dos espaços. São Paulo: Atlas, 2009.

CASELLA, Paulo Borba. Direito internacional no tempo antigo. São Paulo: Atlas, 2012.

CASELLA, Paulo Borba. Direito internacional no tempo clássico. São Paulo: Atlas, 2015.

CASELLA, Paulo Borba. Direito internacional no tempo medieval e moderno até Vitória. São Paulo: Atlas, 2012.

CASELLA, Paulo Borba. Direito internacional no tempo moderno de Suarez a Grócio. São Paulo: Atlas, 2014.

CASELLA, Paulo Borba. Empires, hegemony and cooperation In: ALEXEEVA, Tatiana A.; CATALANO, Pierangelo (coord.). Legal aspects of BRICS = Aspetti giuridici del BRICS. São Petersburgo: Universidade Nacional de Pesquisa, 2011. p. 27-48.

CASELLA, Paulo Borba. Evolução institucional do direito internacional: à luz do cinquentenário do conceito de direito de Hart (1961). Revista Brasileira de Filosofia, São Paulo, ano 60, v. 236, p. 313-329, jan.-jun. 2011.

CASELLA, Paulo Borba. Fundamentos do direito internacional pós-moderno. São Paulo: Quartier Latin, 2008.

CASELLA, Paulo Borba. Il foedus tra plebei e senato ed il problema del diritto internazionale. Dalla secessione della plebe all'autodeterminazione dei popoli.Diritto@ Storia, Rivista Giuridiche e Tradizione Romana, Sassari, v. 9, p. 1-18, 2011.

CASELLA, Paulo Borba. International development law and the right to development in postmodern international law. In: TOUFAYAN, Mark; TOURME-JOUANNET, Emmanuelle; RUIZ FABRI, Hélène (dir.). Droit international et nouvelles approches sur le tiers-monde: entre répétition et renouveau $=$ International law and new approaches to the third world: between repetition and renewal. Paris: Société de législation comparée, 2013. p. 261-280.

CASELLA, Paulo Borba. International law: the post-modern approach to the classics and the new challenges In: COURSE ON INTERNATIONAL LAW, 36., 2009, Rio de Janeiro. Anais [...]. Washington: OEA, 2010.p. 3-46. Disponível em: http://www.oas.org/es/sla/ddi/docs/publicaciones_ digital_XXXVI_curso_derecho_internacional_2009_Paulo_Borba_Casella.pdf.

CASELLA, Paulo Borba. Tratado de Versalhes na história do direito internacional. São Paulo: Quartier Latin, 2007.

CHINOY, Ely. Society: an introduction to sociology. New York: Random House, 1967.

CÍCERO, Marcus Tullius. De officiis. Translation by Walter Miller. Cambridge, MA., 2005.

CLARK, Kenneth. Civilisation: a personal view. Manhattan: Harper \& Row, 1969. 
CLAVIER, Paul. Le concept de monde. Paris: PUF - Presses Universitaires de France, 2000.

DELMAS-MARTY, Mireille. Vers un droit commun de l'humanité: entretien mené par Philippe Petit. Paris: Textuel, 1995.

DELMAS-MARTY, Mireille. Vers un droit commun de l'humanité: entretien mené par Philippe Petit. 2. ed. Paris: Textuel, 2005.

DONNE, John. Devotions upon emergent occasions and several steps in my sickness. Alford, MA: A. M. for Thomas Jones, 1624.

ELIAN, George. Le principe de la souveraineté sur les ressources nationales et ses incidences juridiques sur le commerce international. RCADI - Recueil des Cours - Académie de Droit International de La Haye, [s. l.], t. 149, p. 1-85, 1976.

EPISTOLAE Nicolau I. In: PERELS, Ernst (ed.). Monumenta Germaniae Historica: Epistolae. München: [s. n.], 1985. Tomo 6. p. 658.

FAIRBANK, John King. A preliminary framework. In: FAIRBANK, John King. The Chinese world order: traditional China's foreign relations. Cambridge, MA: Harvard University Press, 1968. p. $1-19$.

FAIRBANK, John King; REISCHAUER, Edwin O. China: tradition \& transformation. Boston: Houghton Mifflin, 1978.

FENWICK, Charles Ghequiere. International law. New York: Appleton-Century, 1934.

FENWICK, Charles Ghequiere. The progress of international law during the past forty years. RCADI - Recueil des Cours - Académie de Droit International de La Haye, [s. l.], t. 79, p. 1-72, 1951.

FLORI, Jean. Guerre sainte, jihad, croisade: violence et religion dans le christianisme et l'islam. Paris: Seuil, 2002.

FOERSTER, Rolf Hellmut. Die idee Europa: 1300-1946: quellen zur geschichte der politischen einigung. München: Dt. Taschenbuch-Verl., 1963.

GABRIELI, Francesco. Effets et influences de l'Islam sur l'europe occidentale. In: PIRENNE, Henri. Mahomet et Charlemagne: Byzance, Islam et Occident dans le Haut Moyen-Age. Trad. de Hélène Seyrès. Milano: Jaca Book, 1987.

GELLIUS, Aulus. Noctes Atticae. With an English translation by John Carew Rolfe. México: Universidad Nacional Autónoma de México, 2006. Livro 6, 3.40.

GHERARI, Habib; SZUREK, Sandra (coord.). L'émergence de la société civile internationale: vers la privatisation du droit international? Paris: Pedone, 2003. (Cahiers internationaux, n. 18). 
GUILLOU, André. Byzance et la genèse de l'europe occidentale. In: PIRENNE, Henri. Mahomet et Charlemagne: Byzance, Islam et Occident dans le Haut Moyen-Age. Trad. de Hélène Seyrès. Milano: Jaca Book, 1987.

HÉRODOTE. L'enquête. Texte présenté, traduit et annoté par Andrée Barguet. In: HÉRODOTE THUCYDIDE. Oeuvres completes. Paris: Gallimard, 1964.

HERÓDOTO. História. Tradução do grego, introdução e notas de Mário da Gama Kury. 2. ed. Brasília: UnB, 1988.

HOSKING, Geoffrey A. Russia and the Russians: from earliest times to the present. London: Penguim, 2012.

HUIZINGA, Johan. La valeur politique et militaire des idées de chevalerie à la fin du Moyen Âge. Revue d'Histoire Diplomatique, Paris, 35e année, p. 126-138, 1921.

INGLEBERT, Hervé. Le Monde, l'histoire: essai sur les histoires universelles. Paris: PUF - Presses Universitaires de France, 2014.

IZENBERG, Gerald N. Modernism and masculinity: Mann, Wedekind, Kandinsky through World War I. Chicago: University of Chicago Press, 2000.

JAEGER, Werner. Paideia: die formung des griechischen menschen. Berlin: Walter de Gruyter, 1936.

KANT, Immanuel. Idéia de uma história universal de um ponto de vista cosmopolita. Tradução Rodrigo Naves e Ricardo R. Terra. 2. ed. São Paulo: Martins Fontes, 2004.

KANT, Immanuel. Logique. Trad. Louis Guillermit. Paris: Vrin, 2007.

KHALDUN, Ibn. Discours sur l'histoire universelle. Paris: Sindbad, 1978. 3 v.

KOETSCHET, Pauline. La philosophie arabe. Paris: Points, 2011.

LE GOFF, Jacques. Pour un autre Moyen Âge: temps, travail et culture en Occident: 18 essais. Paris: Gallimard 2004.

LYON, Bruce. Le débat historique sur la fin du monde antique et le début du moyen âge. In: PIRENNE, Henri. Mahomet et Charlemagne: Byzance, Islam et Occident dans le Haut Moyen-Age. Trad. de Hélène Seyrès. Milano: Jaca Book, 1987.

MAALOUF, Amin. Les croisades vues par les arabes. Paris: J'Ai Lu, 1988.

MACHIAVELLI, Niccolò. Dell'arte della guerra. In: MACHIAVELLI, Niccolò. Tutte le opere. Firenze: Sansoni, 1971. p. 299-398.

MALLAT, Chibli. Introduction to Middle Eastern Law. Oxford: University Press, 2007. 
MEHDI, Rostane. Mutations de la société internationale et adaptations institutionnelles: le grand défi. In: BOISSON DE CHAZOURNES, Laurence; MEHDI, Rostane (dir.). Une société internationale en mutation: quels acteurs pour une nouvelle gouvernance. Bruxelles: Bruylant, 2005. p. 7-18.

MOMIGLIANO, Arnaldo. As raizes clássicas da historiografia moderna. Tradução de Maria Beatriz Borba Florenzano. Bauru: EDUSC, 2004.

NAÇÕES UNIDAS. Carta das Nações Unidas. Rio de Janeiro: Centro de Informação da ONU para o Brasil, 1945. Disponível em: https://nacoesunidas.org/wp-content/uploads/2017/11/A-Carta-das$\mathrm{Na} \% \mathrm{C} 3 \% \mathrm{~A} 7 \% \mathrm{C} 3 \% \mathrm{~B} 5$ es-Unidas.pdf.

NADEAU, Christian; SAADA-GENDRON, Julie. Guerre juste, guerre injuste: histoire, théories et critiques. Paris: PUF, 2009.

NUSSBAUM, Arthur. Historia del derecho internacional: adiciones sobre historia de la doctrina hispánica de derecho internacional por Luis Garcia Arias. Traducción de Francisco Javier Osset. Madri: Revista de Derecho Privado, 1949.

ONUMA, Yasuaki. A normative approach to war: peace, war and justice in Hugo Grotius. Oxford: Clarendon Press, 1993.

ONUMA, Yasuaki. A transcivilizational perspective on international law. Leiden: M. Nijhoff, 2010. PANTER, Barry M. et al. (ed.). Creativity \& Madness: psychological studies of art and artists. Burbank: Aimed Press, 1995.

PIRENNE, Henri. Mahomet et Charlemagne. Bruxelles: Nouvelle societé et édition, 1936.

PIRENNE, Henry. Les villes du Moyen Âge. Paris: PUF - Presses Universitaires de France, 1971.

POLYBE. Histoire. Texte traduit, présenté et annoté par Denis Roussel. Paris: Gallimard, 1970.

RUNCIMAN, Steven. História das Cruzadas. Tradução de Cristiana de Assis Serra. Rio de Janeiro: Imago, 2002. 3v.

SANDBLOM, Philip. Enfermedad y creación: cómo influye la enfermedad en la literatura, la pintura y la música. Madrid: Fondo de Cultura Económica de España, 1995.

SIOTTO-PINTÒR, Manfredi. Les sujets de droit international autres que les états. RCADI-Recueil des Cours - Académie de Droit International de La Haye, [s. l.], t. 41, p. 245-362, 1932.

STEUER, Heiko. De Théodoric le grand à Charlemagne. In: PIRENNE, Henri. Mahomet et Charlemagne: Byzance, Islam et Occident dans le Haut Moyen-Age. Trad. de Hélène Seyrès. Milano: Jaca Book, 1987.

STRENGER, Irineu. Direito internacional privado. 4. ed., aum. e atual. São Paulo: LTr, 2000.

SUR, Serge. L'interprétation en droit international public. Paris: L.G.D.J., 1974.

SUR, Serge. La coutume internationale. Paris: Litec, 1990. 
SUR, Serge. Relations internationales. 3. ed. Paris: Montchrestien, 2004.

SUR, Serge. Système juridique international et utopie. Archives de philosophie du droit, Paris, t. 32, p. 35-45, 1987.

SUR, Serge. Vérification en matière de désarmement. RCADI - Recueil des Cours - Académie de Droit International de La Haye, [s. l.], t. 273, p. 9-102, 1998.

TACHIAOS, Anthony-Emil N., Cirillo e Metodio: le radici cristiane della cultura slava. Milano: Jaca Book, 2005.

THIRLWAY, Hugh. Concepts, principles, rules and analogies: international and municipal legal reasoning. RCADI - Recueil des Cours - Académie de Droit International de La Haye, [s. l.], t. 294, p. 265-406, 2002.

THUCYDIDE. La guerre du Péloponnèse. Texte présenté, traduit et annnoté par Denis Roussel. In: HÉRODOTE - THUCYDIDE. Oeuvres completes. Paris: Gallimard, 1964.

TITO LÍVIO. História de Roma. Introdução, tradução e notas de Paulo Matos Peixoto. São Paulo: Paumape, 1989. 6 v.

TOYNBEE, Arnold Joseph. A study of history. Oxford: Oxford University Press, 1949.

TOYNBEE, Arnold Joseph. Um estudo da história. 2. ed. Brasília: Ed. UnB, 1987.

TUCÍDIDES. História da guerra do Peloponeso. Tradução de Mário da Gama Kury. Brasília: Universidade de Brasília, 1982.

VOLTAIRE. Histoire de l'empire de Russie sous Pierre le grand. [S. l.]: Nabu Press, 2010. p. 337602 .

VOLTAIRE. Oeuvres historiques. Édition établie et annotée par René Pomeau. Paris: Gallimard, 1958.

WITTGENSTEIN, Ludwig. Los cuadernos azul y marrón. Traducción de la 2. ed. Inglesa por Francisco Gracia Guillén. Madrid: Tecnos, 1984.

WITTGENSTEIN, Ludwig. Tractatus logico-philosophicus. London: Routledge \& Kegan Paul, 1961. 